OLIVER, Guillermo. "Modificaciones en la regulación del delito de giro fraudulento de cheque: análisis desde la teoría de la sucesión de leyes".

Polít. crim., Vol. 4, No 7 (Julio 2009), Art. 2, pp. 57-86 (1-30).

[http://www.politicacriminal.cl/Vol_04/n_07/Vol4N7A2.pdf]

\title{
Modificaciones en la regulación del delito de giro fraudulento de cheque: análisis desde la teoría de la sucesión de leyes ${ }^{*}$
}

\author{
Guillermo Oliver Calderón \\ Doctor en Derecho por la Universidad de Barcelona \\ Profesor Adjunto de Derecho Penal en la Pontificia Universidad Católica de Valparaíso \\ guillermo.oliver@ucv.cl
}

\section{Resumen}

Hasta mayo de 2002 el delito de giro fraudulento de cheque era de acción penal pública. El 31 de mayo de ese año se publicó la Ley $\mathrm{N}^{\circ}$ 19.806, que cambió el régimen de la acción penal de dicho delito, el cual pasó a ser en la mayoría de los casos de acción privada. Esta modificación originó el problema de determinar si debía o no aplicarse a los hechos ejecutados con anterioridad a mayo de 2002. Examinando críticamente las distintas opiniones existentes acerca del fundamento de la retroactividad penal in bonam partem y analizando la posibilidad de extender dicho principio a los cambios en la legislación procesal penal, el autor ofrece una solución al problema planteado, concluyendo que la mencionada modificación legal debe aplicarse a los hechos anteriores a su entrada en vigencia.

Palabras clave: Cheque, giro de cheque, giro fraudulento de cheque, acción penal, acción penal pública, acción penal privada, retroactividad, irretroactividad, favorabilidad, idoneidad, necesidad, proporcionalidad, prohibición de exceso, aplicación inmediata, aplicación in actum.

\begin{abstract}
Until May 2002, the check issuance fraud felony was tried through a public penal action. On May $31^{\text {st }}$, 2002, Law $\mathrm{N}^{\circ} 19.806$ was published, substituting the check issuance fraud's penal action regime so that in most cases it is currently tried through a private action. This amendment originated the problem of determining if the new regime should or should not be applied to felonies that occurred before May 2002. Through a critical analysis of current opinions regarding the justification for in bonam partem penal retroactivity as well as an analysis regarding the possibility of extending this principle to penal procedure legislation amendments, the author proposes a solution to the problem, concluding that the legal amendment must also be applied to facts prior to the date the amendment came into force.
\end{abstract}

\footnotetext{
* El presente trabajo ha sido redactado en el marco del proyecto de investigación Fondecyt 1070421, "Formulación de una teoría general de los delitos contra el patrimonio con base en el derecho chileno: estudio dogmático y crítico", ejecutado en la Pontificia Universidad Católica de Valparaíso, en el que el autor se desempeña como investigador responsable. Su contenido corresponde sustancialmente al de algunos capítulos que han servido como fundamento para el análisis del problema abordado, de mi tesis doctoral (especialmente el capítulo IV), cuya primera edición fue publicada con el título "Retroactividad e Irretroactividad de las Leyes Penales", por la Editorial Jurídica de Chile el año 2007. El autor agradece la colaboración prestada en la revisión de aspectos formales del trabajo a la ayudante de Derecho penal de la Pontificia Universidad Católica de Valparaíso, Srta. Carmen Calderón Ortiz.
} 
OLIVER, Guillermo. "Modificaciones en la regulación del delito de giro fraudulento de cheque: análisis desde la teoría de la sucesión de leyes".

Key words: Check, check issuance, check issuance fraud, penal action, public penal action, private penal action, retroactivity, irretroactivity, favorability, suitability, necessity, proportionality, excess prohibition, immediate execution, in actum execution.

\section{Introducción}

Conforme a la normativa vigente hasta mayo de 2002, el delito de giro fraudulento de cheque era de acción penal pública. El 31 de mayo del mencionado año tuvo lugar un cambio en el régimen de la acción penal de dicho delito, al publicarse en el Diario Oficial la Ley $\mathrm{N}^{\circ} 19.806$, que estableció normas adecuatorias del sistema legal chileno a la reforma procesal penal, y cuyo artículo 38 modificó el artículo 42 de la Ley de cheques (cuyo texto refundido, coordinado y sistematizado había sido fijado por el Decreto con Fuerza de Ley No 707, del Ministerio de Justicia, de 7 de octubre de 1982), el cual pasó a tener el siguiente tenor:

"Los delitos previstos y sancionados en el artículo 22 que deriven del giro del cheque efectuado por un librador que no cuente de antemano con fondos o créditos disponibles suficientes en su cuenta corriente, que hubiere retirado los fondos disponibles después de expedido el cheque o hubiere girado sobre cuenta corriente cerrada, conferirán acción penal privada al tenedor del cheque protestado por dichas causales.

Los restantes delitos establecidos en esa disposición y en el artículo 43, darán lugar a acción penal pública, pero los fiscales del Ministerio Público sólo iniciarán la investigación cuando se les presente el cheque protestado y la constancia de haberse practicado la notificación judicial del protesto y de no haberse consignado los fondos en el plazo indicado en el mismo artículo 22, sea que se haya opuesto o no tacha de falsedad en el momento del protesto, o dentro de los tres días siguientes a la notificación judicial del mismo.".

El artículo transitorio de la citada Ley $\mathrm{N}^{\circ} 19.806$ dispuso lo siguiente:

"Las normas de la presente ley entrarán en vigencia a partir de la fecha de su publicación en el Diario Oficial.

Se exceptúan aquellas normas relativas al ejercicio de la acción penal pública, la dirección de la investigación y la protección de las víctimas y testigos; a la competencia en materia penal y a la ley procesal penal aplicable, todas las cuales entrarán en vigencia gradualmente para las Regiones I, XI, XII, V, VI, VIII, X y Metropolitana de Santiago, de conformidad al calendario establecido en el artículo $4^{\circ}$ transitorio de la ley $\mathrm{N}^{\circ} 19.640 . "$.

Esta modificación en la regulación del delito de giro fraudulento de cheque originó el problema de determinar si debía aplicarse o no a los hechos ejecutados con anterioridad a mayo de 2002, conforme al llamado principio de favorabilidad o de retroactividad in bonam partem. El objetivo de este trabajo es analizar si dicho principio resulta aplicable en esta materia. Partiendo de la premisa de que sólo conociendo el fundamento de este principio es posible determinar su alcance sin caer en la arbitrariedad, en la primera parte de este trabajo me dedicaré a reflexionar acerca del porqué de la aplicación retroactiva de las leyes penales favorables, tomando como base distintas opiniones que en la doctrina nacional y comparada se han manifestado sobre el particular. En la segunda parte, sobre la base del fundamento que asigne a dicho principio, analizaré si su radio de acción alcanza o no a las modificaciones benignas en la legislación procesal penal y si tiene importancia asignar a las mencionadas reformas legales naturaleza penal 


\section{Polít. crim., Vol. 4, № 7 (Julio 2009), Art. 2, pp. 57-86 (1-30). \\ [http://www.politicacriminal.cl/Vol_04/n_07/Vol4N7A2.pdf]}

sustantiva o adjetiva. En la tercera y última parte examinaré el problema planteado, sugiriendo la forma en que creo debería solucionarse.

\section{Fundamento del principio de retroactividad de la ley penal más favorable}

En la doctrina se han planteado diversas opiniones para explicar la razón por la cual las leyes penales son retroactivas cuando resultan más favorables. ${ }^{1}$ A continuación, analizo distintas posturas que sobre este tema se han formulado.

\subsection{Consideraciones de justicia}

Algunos autores han señalado que son razones de justicia las que explican la aplicación retroactiva de las disposiciones penales más favorables. Es el caso, por ejemplo, de Maurach, quien afirma que

"la rigurosa aplicación de la prohibición de retroactividad encuentra sus fronteras allí donde, en lugar de cumplirse el fin perseguido por la irretroactividad protección del autor frente a las penas 'sobrevenidas'-, se produciría un perjuicio para el sujeto. Toda modificación legal es signo de un cambio valorativo; por la supresión o atenuación de la amenaza penal, manifiesta el legislador una revisión de su concepción primitiva a favor de una más suave. Si se quisiera mantener aquí la prohibición de retroactividad, debería ser castigado el autor sobre la base de una concepción jurídica no profesada ya por el propio legislador. Con el objeto de evitar esta violación de la justicia material, se prevé la obligatoria retroactividad de la ley más benigna".2

Es ésta una posición doctrinal que puede ser calificada como dominante, ${ }^{3}$ dada su gran aceptación entre los autores, sea que aludan a la justicia como única fundamentación ${ }^{4}$ de

\footnotetext{
${ }^{1}$ Véase una detallada exposición de ellas en OLIVER CALDERÓN, Guillermo, Retroactividad e irretroactividad de las leyes penales, Santiago: Editorial Jurídica de Chile, 2007, pp. 262 y ss.

${ }^{2}$ MAURACH, Reinhart, Tratado de Derecho Penal, Trad. CÓRDOBA RODA, Juan, Barcelona: Ariel, 1962, pp. 142 y s. (las cursivas son mías).

${ }^{3}$ Así lo considera, junto con la posición doctrinal que alude a consideraciones humanitarias, que se analiza más adelante, SILVA SÁNCHEZ, Jesús María, "Legislación penal socio-económica y retroactividad de disposiciones favorables: el caso de las 'leyes en blanco'", en: ARROYO ZAPATERO, Luis et al, Hacia un derecho penal económico europeo, Madrid: BOE, 1995, pp. 697-722, p. 699, nota 9. En contra, DE VICENTE MARTÍNEZ, Rosario, El principio de legalidad penal, Valencia: Tirant lo Blanch, 2004, p. 65, y FRÍGOLS I BRINES, Eliseu, Fundamentos de la sucesión de leyes en el derecho penal español. Existencia y aplicabilidad temporal de las normas penales, Barcelona: Bosch, 2004, p. 407 , señalando la primera que la mayor parte de la doctrina (española) se muestra partidaria de entender que el fundamento de la retroactividad in bonam partem se halla en razones político-criminales reconducibles a las exigencias del principio de prohibición de exceso, y afirmando el segundo que la mayoría de los autores advierte dicho fundamento en el principio de necesidad de las penas.

${ }^{4}$ Cfr., entre otros, GALLEGO DÍAZ, Manuel, "Prescripción penal y prohibición de retroactividad", Revista General de Legislación y Jurisprudencia, enero (1986), pp. 27-48, p. 28; FIORE, Pascuale, De la irretroactividad e interpretación de las leyes. Estudio crítico y de legislación comparada, $3^{\mathrm{a}}$ edición, Trad. AGUILERA DE PAZ, Madrid: Reus, 1927, pp. 441 y ss.; CUELLO CONTRERAS, Joaquín, $E l$ Derecho Penal español. Parte general, $3^{\text {a }}$ edición, Madrid: Dykinson, 2002, pp. 246 y ss.; RODRÍGUEZ MOURULlO, Gonzalo, Derecho Penal. Parte General, Madrid: Civitas, 1978, pp. 132 y ss. (ver sin embargo, EL MISMO, Delito y pena en la jurisprudencia constitucional, Madrid: Civitas, 2002, p. 47, agregando a la idea de justicia consideraciones de proporcionalidad, y EL MISMO, "Comentario al art. 2", en: RODRÍGUEZ MOURULLO (dir.); JORGE BARREIRO (coord.), Comentarios al Código Penal, Madrid: Civitas, 1997, p. 31, añadiendo a las razones de justicia la idea de seguridad jurídica); OCTAVIO DE TOLEDO Y UBIETO, Emilio, Sobre el concepto del Derecho penal, Madrid: Facultad de Derecho de
} 
OLIVER, Guillermo. "Modificaciones en la regulación del delito de giro fraudulento de cheque: análisis desde la teoría de la sucesión de leyes".

la retroactividad de la ley penal más favorable, o que la mencionen como basamento adicional a otra u otras razones. 5

Sin embargo, a mi juicio, no puede considerarse a la justicia como el motivo que explique por qué las leyes penales deben ser aplicadas retroactivamente cuando resulten más favorables. Ello es así, porque las mismas razones que suelen esgrimirse para sostener que sería injusto no aplicar en forma retroactiva una ley penal más benigna, que evidencia un cambio en la valoración de la conducta enjuiciada, podrían invocarse para justificar la aplicación retroactiva de leyes penales más severas que las anteriores, en tanto también demuestran un cambio valorativo del legislador. ${ }^{6}$ En efecto, si, como afirma Maurach, castigar al autor sobre la base de una concepción jurídica no profesada ya por el legislador significara una violación de la justicia material, no sólo sería injusto no aplicar retroactivamente una ley penal más benigna que la anterior, sino que también lo sería negar dicha aplicación a una nueva ley más severa que la antigua. Y así se justificaría la retroactividad de todas las leyes penales, tanto las más favorables, como las menos benignas. ${ }^{7}$ Por ejemplo, según un importante sector doctrinal, habrían sido

la Universidad de Madrid, 1981, p. 325; PESSINA, Enrique, Elementos de Derecho Penal, 4a edición, Trad. GONZÁLEZ DEL CASTILLO, Hilarión, prologado y adicionado con arreglo al derecho español por Félix de Aramburu y Zuloaga, anotada conforme a la legislación vigente y adicionada con las doctrinas científicas modernas por Eugenio Cuello Calón, Madrid: Reus, 1936, p. 214. En la doctrina colombiana, MEJÍA ESCOBAR, Carlos, "Apunte sobre la favorabilidad", Temas de Derecho Penal Colombiano, $\mathrm{n}^{\mathrm{o}}$ 14, (1981), pp. 47-57, p. 48. En la doctrina chilena, NOVOA MONREAL, Eduardo, Curso de Derecho Penal Chileno, t. I, $2^{\text {a }}$ edición, Santiago: Editorial Jurídica Ediar-Conosur, 1985, pp. 199 y ss.

5 Así, entre otros, LUZÓN PEÑA, Diego-Manuel, Curso de Derecho penal. Parte general, t. I, Madrid: Universitas, 1996, p. 183; ANTÓN ONECA, José, Derecho Penal, 2a edición anotada y puesta al día por José Julián Hernández Guijarro y Luis Beneytez Merino, Madrid: Akal, 1986, pp. 126 y ss.; SÁINZ CANTERO, José, Lecciones de Derecho Penal. Parte general, $3^{\mathrm{a}}$ edición, Barcelona: Bosch, 1990, pp. 398 y ss.; SERRANO BUTRAGUEÑO, Ignacio, "Retroactividad, ultra-actividad y extractividad de las normas penales", La Ley, No 4530, 29 de abril de 1998, pp.1-6, p. 2; RUIZ DE ERENCHUM ARTECHE, Eduardo, "El 'sistema de sucesión de leyes' y la problemática de la redención de penas por el trabajo. Valoración de las aportaciones del Tribunal Supremo", Revista del Poder Judicial, No 48, (1997), pp. 323-386, p. 331; PUENTE SEGURA, Leopoldo, "Delitos contra la salud pública. Posibilidad de revisión de sentencias al amparo del nuevo artículo 376 del Código Penal", La Ley 2004-5,pp. 1298-1303, p. 1302. En la doctrina francesa, MATHIEU, Gilles, "L'application de la loi pénale dans le temps (dans la perspective du nouveau Code Pénal)", Revue de Science Criminelle et de Droit Pénal Comparé, (1995), pp. 257-270, p. 263; THÉODOSIADÉS, Miltiade, Essai sur la non-rétroactivité des lois, París: Abel Pilon, 1866, p. 199. En la doctrina brasileña, LEIRIA, Antònio José Fabricio, Teoria e aplicação da lei penal, Sao Paulo: Saraiva, 1981, p. 79. En la doctrina chilena, LABATUT GLENA, Gustavo, Derecho Penal, t. I, 9a edición actualizada por el profesor Julio Zenteno Vargas, Santiago: Editorial Jurídica de Chile, 2000, p. 51.

${ }^{6}$ Ver BÉRAUD, R., "La non-rétroactivité des lois nouvelles plus douces?", Revue de Science Criminelle et de Droit Pénal Comparé, enero - marzo (1949), no 1, pp. 7-20, p. 16, quien sostiene que la idea de justicia incluso impide la aplicación retroactiva de leyes penales favorables posteriores al hecho enjuiciado.

${ }^{7}$ Cfr. la crítica, en el sentido indicado en el texto, de CASABÓ RUIZ, José Ramón, "Comentario al art. 24” en: CÓRDOBA RODA, Juan; RODRÍGUEZ MOURULLO, Gonzalo; DEL TORO MARZAL, Alejandro; CASABÓ RUIZ, José Ramón, Comentarios al Código Penal, t. II, Barcelona: Ariel, 1972, pp. 44-58, p. 46; CEREZO MIR, Curso de Derecho penal español. Parte general, t. I, 6 a edición, Madrid: Tecnos, 2004, p. 227; LANDROVE DÍAZ, Gerardo, Introducción al Derecho Penal español, $5^{\text {a }}$ edición revisada y puesta al día en colaboración con María Dolores Fernández Rodríguez, Madrid: Tecnos, 2000, pp. 119 y ss.; LANDECHO VELASCO, Carlos María; MOLINA BLÁZQUEZ, Concepción, Derecho Penal Español. Parte general, $7^{\text {a }}$ edición, Madrid: Tecnos, 2004, p. 153; MORILLAS CUEVA, Lorenzo, Derecho Penal. Parte General. Fundamentos conceptuales y metodológicos del Derecho penal. Ley penal, Madrid: Dykinson, 2004, p. 219; MORILLAS CUEVA, Lorenzo; RUIZ ANTÓN, Luis Felipe, 
precisamente razones de justicia las que llevaron a la aplicación retroactiva de leyes penales para castigar los crímenes cometidos en el régimen nazi, que de otro modo, hubieran quedado sin sanción.

\subsection{Razones humanitarias}

Es posible encontrar también en la doctrina opiniones que, para explicar cuál es el fundamento que justifica la retroactividad de las leyes penales más benignas, giran en torno a la idea de razones humanitarias. Así, por ejemplo, Cuerda Riezu sostiene que

"sólo cabe entender la retroactividad favorable por razón de humanidad, pietatis causa". 8

Junto con la posición doctrinal que ve en la justicia el fundamento de la retroactividad penal favorable, puede afirmarse que esta opinión es mayoritaria entre los autores, ${ }^{9}$ bien consideren a las razones humanitarias como única justificación, ${ }^{10}$ bien lo hagan en conjunto con otras razones. ${ }^{11}$

Manual de Derecho Penal (parte general), Madrid: Editoriales de Derecho Reunidas, 1992, p. 85. Similar, en la doctrina italiana, SPASARI, Mario, Diritto Penale e Costituzione, Milán: Giuffrè, 1966, p. 42. En la doctrina francesa, ROUBIER, Paul, Le Droit Transitoire (conflits des lois dans le temps), $2^{\mathrm{a}}$ edición, París: Dalloz et Sirey, 1960, p. 453. En la doctrina argentina, FIERRO, Guillermo, Legalidad y retroactividad de las normas penales. Fuentes del derecho. Legalidad en el derecho tributario, procesal penal y aduanero, Buenos Aires: Hammurabi, 2003, pp. 312 y ss.

${ }^{8}$ CUERDA RIEZU, Antonio, "La aplicación retroactiva de las leyes favorables y el principio de legalidad penal en clave constitucional” en: BALADO, M.; GARCÍA REGUEIRO, J. A.; (dirs.), La Declaración Universal de los Derechos Humanos en su 50 aniversario, Barcelona: Bosch, 1998, pp. 275-290, p. 290.

9 Como lo reconocen CASABÓ, "Comentario", cit. nota no 7, p. 46; SILVA SÁNCHEZ, "Legislación penal socio-económica”, cit. nota n 3, p. 699, nota 9. En contra, FRÍGOLS I BRINES, Fundamentos, cit. nota $\mathrm{n}^{\circ} 3$, p. 407; DE VICENTE, El principio de legalidad penal, cit. nota $\mathrm{n}^{\circ}$ 3, p. 65.

${ }^{10}$ Cfr. PACHECO, Joaquín Francisco, El Código Penal concordado y comentado, reimpresión de la $3^{\mathrm{a}}$ edición de 1867, Madrid: Edisofer, 2000, p. 303; CUELLO CALÓN, Eugenio, Adiciones a la $4^{a}$ edición de la traducción de Elementos de derecho penal de Enrique Pessina, Madrid: Reus, 1936, pp. 220 y ss.; LANDROVE DÍAZ, Introducción al Derecho Penal español, cit. nota nº7, pp. 119 y s.; LANDECHO / MOLINA, Derecho Penal Español, cit. nota n 7, p. 152; DEL ROSAL, Juan, "Consumación y aplicación de ley penal en el delito continuado", Anuario de Derecho Penal y Ciencias Penales, (1948), pp. 277-291, p. 286. En la doctrina italiana, PATALANO, Vicenzo, "Reato permanente e successione di leggi penali nel tempo", Giurisprudenza di Merito, Parte Segunda, (1975), pp. 54-60, p. 60. En la doctrina belga, HENNAU, Christiane; VERHAEGEN, Jacques, Droit Pénal General, $2^{\text {a }}$ edición, Bruselas: Bruylant, 1995, p. 87. En la doctrina colombiana, VELÁSQUEZ VELÁSQUEZ, Fernando, Derecho Penal. Parte General, $3^{a}$ edición, Bogotá: Temis, 1997, p. 145. En la doctrina brasileña, DUARTE, José, “A lei penal no tempo. Comentários ao art. $2^{\circ}$ do Código Penal", Revista Forense, volumen XC, Sao Paulo, (1942), pp. 622-631, p. 626. En la doctrina argentina, DRAGONETTI, Mario, “¿Irretroactividad de la ley penal más benigna en materia de infracciones a la ley 12.830? El código penal como derecho represivo común en situaciones anteriores a la ley 13.492", Revista Jurídica Argentina La Ley, $\mathrm{n}^{\circ}$ 52, Buenos Aires, octubre - diciembre (1948), pp. 433-439, p. 435.

${ }^{11}$ Ver LUZÓN PEÑA, Curso, cit. nota no 5, p. 183; ANTÓN ONECA, Derecho Penal, cit. nota $\mathrm{n}^{\circ}$ 5, p. 126; SÁINZ CANTERO, Lecciones de Derecho Penal, cit. nota n ${ }^{\circ}$ 5, pp. 398 y s.; CEREZO MIR, Curso de Derecho penal español, t. I, cit. nota $\mathrm{n}^{\circ}$ 5, p. 227; SERRANO, "Retroactividad, ultra-actividad y extractividad", cit. nota $n^{\circ} 5$, p. 2; PUENTE, "Delitos contra la salud pública", cit. nota no 5, p. 1302. En la doctrina francesa, THÉODOSIADÈS, Essai sur la non-rétroactivité des lois, cit. nota no 5, p. 199. En la doctrina belga, RUBBRECHT, J.; DECLERCQ, R., "La non-rétroactivité des lois pénales en Droit Belge", Revue de Droit International et de Droit Comparé, Bruselas: (1950), XXVII, número especial, pp. 214-221, p. 216. En la doctrina ecuatoriana, ALBÁN GÓMEZ, Ernesto, Manual de Derecho Penal Ecuatoriano, Quito: Ediciones Legales, 1995, pp. 59 y ss. En la doctrina brasileña, LEIRIA, Teoria $e$ aplicação, cit. nota $\mathrm{n}^{\circ}$ 5, p. 79. En la doctrina chilena, LABATUT, Derecho Penal, t. I, cit. nota $\mathrm{n}^{\circ}$ 5, p. 51. 
OLIVER, Guillermo. "Modificaciones en la regulación del delito de giro fraudulento de cheque: análisis desde la teoría de la sucesión de leyes".

Sin embargo, pienso que tampoco puede afirmarse que sean, simplemente, consideraciones de tipo humanitario las que expliquen por qué se aplican retroactivamente las leyes penales cuando son más favorables que las anteriores. ${ }^{12} \mathrm{Si}$ fuera éste el verdadero fundamento, el legislador podría declarar que una nueva ley más favorable que la anterior no produzca efecto retroactivo, en caso que decidiera no tomar en cuenta razones humanitarias de ninguna clase. Ello, porque no existe ningún límite al ejercicio de la potestad punitiva estatal que obligue al legislador a ser piadoso, a tener en consideración razones humanitarias al momento de crear leyes penales. Si lo hubiera, sería una verdadera obligación suya dictar cada cierto tiempo leyes de amnistía en relación con toda clase de delitos -iqué mejor forma de demostrar piedad!-, lo que resultaría francamente inaceptable.

Del examen de los diversos límites al ius puniendi, tanto formales, como materiales, que los distintos autores reconocen, se colige que el que más se asemejaría es el denominado principio de humanidad. ${ }^{13}$ Pero este principio, en general, se suele concebir como referido a las penas, en el sentido de exigir una cada vez menor intensidad de su aflictividad y menor duración, y de constatar que, históricamente, así ha ocurrido. En consecuencia, no puede extraerse de él la exigencia de que el legislador penal sea piadoso, por lo que, atendiendo sólo a este punto de vista, no habría inconveniente en que aquél declarase que una nueva ley más favorable no tenga efecto retroactivo.

No obstante, los autores sostienen que las leyes penales más benignas deben siempre tener efecto retroactivo, afirmación con la que, en principio, estoy de acuerdo, pero que, en mi opinión, demuestra que la retroactividad penal favorable no tiene su explicación en supuestas consideraciones humanitarias, sino en otra clase de razones.

\subsection{Fines de defensa social}

En la doctrina se han planteado también opiniones que señalan que puede encontrarse un fundamento de la retroactividad de las leyes penales más favorables en consideraciones de defensa social. Es el caso, por ejemplo, de Antón Oneca, quien junto con aludir a razones humanitarias y de justicia, explica que

"la ley nueva expresa las exigencias de la defensa social y las concepciones éticojurídicas dominantes en el momento de su nacimiento. Toda ley penal debería ser retroactiva". ${ }^{14}$

En mi opinión, sin embargo, no resulta satisfactorio afirmar que sean razones de defensa social las que expliquen por qué las leyes penales deben ser retroactivas cuando sean

\footnotetext{
${ }^{12}$ Ver ROBERT, Jacques-Henri, Droit pénal general, $3^{\text {a }}$ edición, París: Presses Universitaires de France, 1998, p. 144: "La préférence donnée à l'application, par le juge, de la loi la plus douce n'est pas le fruit d'une hypothétique clémence ou miséricorde judiciaire".

${ }^{13}$ Cfr., en relación con el principio de humanidad, entre otros, MIR PUIG, Santiago, Derecho Penal. Parte General, $7^{\mathrm{a}}$ edición, Barcelona: Reppertor, 2004, pp. 131 y ss.; LUZÓN PEÑA, Curso, cit. nota n ${ }^{\circ}$ 5, pp. 80 y ss.; SILVA SÁNCHEZ, Jesús María, Aproximación al derecho penal contemporáneo, Barcelona: Bosch, 1992, p. 261; COBO DEL ROSAL, Manuel; VIVES ANTÓN, Tomás Salvador, Derecho Penal. Parte General, $5^{\text {a }}$ edición, Valencia: Tirant lo Blanch, 1999, pp. 99 y ss.; JESCHECK, Hans-Heinrich, Tratado de derecho penal. Parte general, Trad. MANZANARES SAMANIEGO, José Luis, de la $4^{a}$ edición alemana, Granada: Comares, 1993, p. 23.

${ }^{14}$ ANTÓN ONECA, Derecho Penal, cit. nota n ${ }^{\circ}$ 5, p. 126 (las cursivas son mías).
} 
más benignas. Puede sostenerse aquí la misma argumentación que esgrimí para rechazar que pueda verse en la idea de justicia el fundamento de la retroactividad penal favorable. En efecto, si, como sostiene Antón Oneca, la nueva ley expresa las exigencias de defensa social y las concepciones ético-jurídicas dominantes en el momento de su promulgación, no se divisa la razón por la que sólo deban ser retroactivas las leyes penales más favorables. En las leyes penales más severas también se expresan aquellas exigencias y concepciones, por lo que una fundamentación que apunte a fines de defensa social debería, necesariamente, conducir a la aplicación retroactiva de todas las leyes penales, tanto las perjudiciales, como las benignas. ${ }^{15}$ Por lo tanto, creo que la explicación de por qué las leyes penales más favorables tienen efecto retroactivo debe ser buscada, acudiendo a otra clase de consideraciones.

\subsection{Cambio en la valoración de la conducta}

Se ha sostenido también por algún autor que el fundamento de la retroactividad de las leyes penales más favorables se encuentra en la modificación de la valoración que la sociedad hace de ciertos comportamientos. Así, por ejemplo, Serrano Alberca señala que el fundamento de las disposiciones que asignan efecto retroactivo a las leyes penales más benignas,

"se encuentra más que en razones humanitarias, en el cambio valorativo de la conducta operado en el ordenamiento jurídico". ${ }^{16}$

No creo que se pueda sostener que el fundamento de la aplicación retroactiva de las leyes penales más favorables sea sólo el cambio valorativo de la conducta. Desde luego, si se produce una modificación en la legislación penal para atenuar su rigor -o bien para aumentarlo-, es porque probablemente ha habido un cambio en la valoración social de determinados comportamientos humanos. Pero este cambio valorativo, por sí solo, no explica por qué la nueva normativa tenga que ser aplicada con efecto retroactivo. Lo único que explica es la necesidad de adaptar la legislación penal a la nueva valoración social. Por lo tanto, afirmar que es el cambio valorativo de la conducta el fundamento de la retroactividad de las leyes penales más favorables, me parece una argumentación incompleta, que requiere de un paso más en la búsqueda de aquella fundamentación.

Por otra parte, podría repetir aquí la misma crítica que hice más arriba frente a la posición doctrinal que ve en la idea de justicia o en fines de defensa social el fundamento de la retroactividad de las leyes penales más benignas. En efecto, aun si se aceptara que lo que justifica la aplicación retroactiva de las leyes penales más favorables es el cambio en la valoración de la conducta, no se divisaría la razón por la cual no puedan tener efecto retroactivo las leyes penales más severas, en tanto éstas también son expresión de una nueva valoración del comportamiento. Acudir a la idea de

\footnotetext{
${ }^{15}$ En el sentido del texto, en la doctrina italiana, ya ARANGIO RUIZ, Gaetano, "Intorno all'efficacia delle leggi penali temporanee", Rivista Penale, No 44, (1896), pp. 5-22, p. 10.

16 SERRANO ALBERCA, José Manuel, "Comentario al art. 25 de la Constitución” en: GARRIDO FALLA, Fernando et al, Comentarios a la Constitución, $3^{\text {a }}$ edición, Madrid: Civitas, 2001, pp. 577-612, p. 585 (las cursivas son mías). En el mismo sentido, DE LUCA, La garantía constitucional de retroactividad de ley penal más benigna y su violación en las leyes penales económicas en blanco con el pretexto de subsistencia de la lesión al bien jurídico protegido, ponencia presentada en la Comisión $\mathrm{V}$ del Congreso Internacional de Derecho Penal " $75^{\circ}$ Aniversario del Código Penal”, organizado por la Facultad de Derecho y Ciencias Sociales de la Universidad de Buenos Aires, Argentina, entre el 11 y el 14 de agosto de 1997, p. 4. Ver también ALBÁN GÓMEZ, Manual, cit. nota no 11, pp. 59 y s.
} 
OLIVER, Guillermo. "Modificaciones en la regulación del delito de giro fraudulento de cheque: análisis desde la teoría de la sucesión de leyes".

modificación en la valoración serviría entonces para justificar la aplicación retroactiva de todas las leyes penales, tanto las favorables, como las desfavorables. Luego no puede encontrarse aquí el verdadero fundamento de la retroactividad de las leyes penales más benignas.

\title{
1.5. Principio de igualdad ante la ley
}

Es posible también encontrar en la doctrina opiniones que, buscando un fundamento para la aplicación retroactiva de las leyes penales más favorables, acuden al denominado principio de igualdad ante la ley. Es el caso, verbigracia, de Pérez Royo, quien afirma que

\begin{abstract}
"para encontrar una fundamentación acabada de la regla que ocupa nuestra atención [la de la retroactividad de las leyes penales más benignas], ha de tenerse en cuenta [...] la exigencia de igualdad, en los términos específicos en que ésta se recoge tradicionalmente en la aplicación de las normas penales. Efectivamente, lo que de manera expresa ha querido el legislador es que, a la hora de valorar la antijuridicidad de una conducta o el merecimiento de pena para la misma, el juzgador aplique la norma vigente en el momento del juicio (e incluso más allá, mientras persista la pena), valorando por igual las conductas cometidas antes y después de la entrada en vigor de esa norma, siempre que de ella se derive un resultado más favorable para el reo". ${ }^{17}$
\end{abstract}

Me parece que tampoco puede verse en la igualdad ante la ley el fundamento de la aplicación retroactiva de las leyes penales más favorables. ${ }^{18}$ La exigencia de igualdad

\footnotetext{
${ }^{17}$ PÉREZ ROYO, Fernando, "La aplicación retroactiva de la ley penal más favorable en los casos de modificaciones en la normativa tributaria", Revista Técnica Tributaria $\mathrm{n}^{\circ} 43$, octubre - diciembre (1998), pp. $75-88$, pp. 78 y s. (las cursivas son mías), aludiendo también, como fundamento de la retroactividad de las leyes penales más favorables, a los principios de intervención mínima y de prohibición de exceso. Cfr., asimismo, GONZÁLEZ TAPIA, María Isabel, Determinación del tiempo de comisión del delito, Granada: Comares, 2002, pp. 223 y ss., considerando el principio de igualdad como un argumento "mediato" para justificar la retroactividad penal favorable. Las argumentaciones que giran en torno a la igualdad ante la ley para fundamentar la retroactividad in bonam partem, han tenido gran acogida en la doctrina en Italia. Lo reconoce FRÍGOLS I BRINES, Eliseu, El principio de irretroactividad y la sucesión de leyes penales. Una perspectiva desde el derecho comparado, San José de Costa Rica: Editorial Jurídica Continental, 2002, p. 201, quien sostiene que se trata de la tesis dominante en dicho país. Cfr., entre otros, CARNELUTTI, Francesco, "Riflessioni sulla successione di leggi penali processuali" en EL MISMO, Questioni sul processo penale, Bolonia: Cesare Zuffi, 1950, pp. 187-200, p. 191; MANTOVANI, Fernando, Diritto Penale. Parte Generale, $3^{\text {a }}$ edición, Padova: Cedam, 1992, pp. 118 y ss.; FIANDACA, Giovanni; MUSCO, Enzo, Diritto Penale. Parte Generale, $3^{\text {a }}$ edición, Bolonia: Zanichelli, 1995, reimpresión, 1999, p. 79; PALAZZO, Francesco, Introduzione ai principi del Diritto penale, Turín: Giappichelli, 1999, p. 296; PADOVANI, Tullio, "Decreto-legge non convertito e norme penali di favore, in bilico tra opposte esigenze costituzionali", Rivista Italiana di Diritto e Procedura Penale, 1985, pp. 819-835, pp. 826 y ss.; EL MISMO, "Tipicità e successione di leggi penali. La modificazione legislativa degli elementi della fattispecie incriminatrice o della sua sfera di applicazione, nell'ambito dell'art. $2,2^{\circ}$ e $3^{\circ}$ comma, C.P.", Rivista Italiana di Diritto e Procedura Penale, (1982), pp.1354-1389, pp. 1378 y s.; CARACCIOLI, Ivo, Manuale di Diritto Penale. Parte generale, Padova: Cedam, 1998, p. 90; PULITANÒ, Domenico, "Commentario al articolo 2" en: CRESPI, Alberto; STELLA, Federico; ZUCCALÀ, Giuseppe, Comentario breve al Codice Penale, Padova: Cedam, 2003, pp. 17-28, p. 17; VASSALLI, Giuliano, "Abolitio criminis e principii costituzionali", Rivista Italiana di Diritto e Procedura Penale, (1983), pp. 377-414, p. 408.

${ }^{18}$ Cfr. COBO DEL ROSAL / VIVES ANTÓN, Derecho Penal. Parte General, cit. nota no 13, p. 196, considerando más que discutible la derivación de la retroactividad de la ley penal más favorable, directamente, del principio de igualdad ante la ley. Ver también FRÍGOLS I BRINES, Fundamentos, cit. nota $\mathrm{n}^{\circ} 3$, pp. $417 \mathrm{y}$ ss.
} 
podría servir para explicar por qué el efecto retroactivo de las leyes penales más benignas beneficia, sin distinción alguna, a todas las personas que hubiesen realizado conductas delictivas con anterioridad a su entrada en vigor. Pero no da respuesta a la pregunta de por qué resulta obligatorio dar efecto retroactivo a aquellas leyes. Luego no puede servir por sí sola de fundamento de dicha retroactividad.

Además, la exigencia de igualdad resultaría respetada, aun cuando no se diera aplicación retroactiva a las leyes penales más favorables y se mantuviera una irretroactividad absoluta de toda ley penal, porque el principio de igualdad obliga a tratar en forma igual situaciones iguales y de manera desigual situaciones diferentes. Entre quienes realizan una conducta delictiva durante la vigencia de una ley penal más severa y quienes actúan estando en vigor una ley nueva más benigna, existe una diferencia fundamental: los primeros infringen una norma primaria, en tanto que los segundos no lo hacen; o bien, ambos contravienen una norma primaria, pero aquéllos lo hacen en un momento en que la norma secundaria establece un tratamiento jurídicopenal más duro que el contenido en la norma secundaria bajo la vigencia de la cual lo hacen éstos. Por lo tanto, un estricto respeto del principio de igualdad podría conducir a negar aplicación retroactiva a las leyes penales más favorables, consagrándose un sistema de absoluta irretroactividad de toda ley penal. ${ }^{19}$

Por otro lado, la argumentación de Pérez Royo, que parte de la base de que la regla general es la aplicación por el juez del Derecho vigente en el momento de la sentencia, o sea, la retroactividad, salvo que ello conduzca a un resultado desfavorable para el reo, es de difícil aplicación en Chile. Ello es así, porque, de conformidad con lo previsto en el artículo 18, inciso tercero, del Código Penal, la retroactividad de las leyes penales más favorables se extiende incluso a los casos en que ya existe sentencia de término, se haya cumplido o no la condena. ${ }^{20}$ Luego no puede explicarse dicha retroactividad como la simple aplicación por el juzgador del Derecho vigente al momento de dictar sentencia. $^{21}$

\subsection{Principio de legalidad}

También se encuentran en la doctrina opiniones que señalan que el fundamento de la retroactividad de las leyes penales más favorables se halla en el principio de legalidad. En este sector doctrinal destaca Huerta Tocildo, quien afirma que

"el principio de legalidad penal tiene también atribuida una función de garantía de la libertad individual que quedaría empañada, por no decir anulada, si la ley posterior más favorable, ya sea porque convierte en lícito lo que antes era ilícito, ya sea porque reduce la pena que previamente correspondía a ese mismo hecho, careciera de incidencia respecto de las conductas llevadas a cabo bajo la vigencia de la ley a la que ha venido a sustituir. Incidencia que, por lo acabado de decir, no

\footnotetext{
${ }^{19}$ En este sentido, véanse las argumentaciones de CADOPPI, Alberto, "Il principio di irretroattività" en: INSOLERA, G.; MAZZACUVA, N.; PAVARINI, M.; ZANOTTI, M. (a cura di), Introduzione al sistema penale, vol. I,Turín: Giappichelli, 1997, pp. 154-189, p. 171; TAIPA DE CARVALHO, Americo, Sucessão de leis penais, Coimbra: Coimbra Editora, 1990, p. 195.

${ }^{20}$ Otro tanto ocurre en España, de conformidad con el artículo 2.2 de su Código Penal. No sucede lo mismo en Alemania, país en cuyo Código Penal se fija como límite para la aplicación retroactiva de las leyes penales más favorables, el momento en que se dicta la sentencia (parágrafo 2).

${ }^{21}$ Cfr. una crítica a similar argumentación de Klaus Tiedemann, en SILVA SÁNCHEZ, Legislación penal socio-económica, cit. nota $\mathrm{n}^{\mathrm{o}} 3$, p. 697 , nota 1 .
} 
OLIVER, Guillermo. "Modificaciones en la regulación del delito de giro fraudulento de cheque: análisis desde la teoría de la sucesión de leyes".

trae por fundamento, como frecuentemente ha sostenido la doctrina, motivos "pietistas" o humanitarios, ni obedece a una concesión "graciosa" del legislador, sino que le vincula, al ser una derivación más del significado político y democrático del principio consagrado en el art. 25.1 C.E. y de su función de garantía de la libertad individual, que impide que se sigan restringiendo los derechos fundamentales de los ciudadanos cuando ello ya no se juzga necesario, o que pervivan unas sanciones cuya gravedad ha sido cualitativa o cuantitativamente atenuada". 22

Es decir, esta autora sostiene que el fundamento de la retroactividad de las leyes penales más benignas se encuentra, en último término, en el principio de legalidad penal, al cual ella le atribuye una función de garantía de la libertad individual. ${ }^{23}$

No me parece que el fundamento de la aplicación retroactiva de las leyes penales favorables sea el principio de legalidad penal. Al aparecer en las primeras Declaraciones, Convenciones Internacionales sobre Derechos Humanos y Constituciones, el principio de legalidad penal fue consagrado a través de una prohibición de retroactividad de las leyes penales, pero sin ninguna alusión a la retroactividad de las leyes penales más benignas. Fue con posterioridad cuando comenzó a reconocerse en algunos Tratados Internacionales y en ciertas Constituciones, la retroactividad in bonam partem. Y es comprensible que así haya sido, porque la irretroactividad de las leyes penales, parte integrante del contenido que se suele asignar al principio de legalidad, tiene un indudable carácter de garantía para los ciudadanos, en el sentido de protegerles frente a eventuales condenas sorpresivas o aumentos de pena ex post facto, permitiéndoles adecuar sus comportamientos a los mandatos $\mathrm{y}$ prohibiciones legales. O sea, haciendo posible que sepan a qué atenerse, cautelándose así la seguridad jurídica. En cambio, la retroactividad de lo favorable no representa ninguna garantía para las personas, ya que nadie puede saber, en el momento en que comete un delito, que vaya a promulgarse con posterioridad una ley que despenalice el hecho o le asigne una pena menos rigurosa. Y, por otra parte, no existiría en este caso ningún peligro de producción de un mal, del cual proteger a los ciudadanos, sino que, al contrario, una mera posibilidad de que a futuro se dicte una nueva ley penal que establezca un tratamiento más benigno para el hecho realizado, por lo que mal puede decirse que la aplicación retroactiva de las eventuales leyes penales más favorables que

\footnotetext{
${ }^{22}$ HUERTA TOCILDO, Susana, "Principio de legalidad y normas sancionadoras" en: El principio de legalidad. Actas de las V Jornadas de la Asociación de Letrados del Tribunal Constitucional. Cuadernos y Debates, $\mathrm{N}^{\circ}$ 103, Madrid, 2000, pp. 11-76, p. 35 (el destacado en cursiva es mío y se explica por consideraciones que efectúo más abajo). También LA MISMA, "El derecho fundamental a la legalidad penal”, Revista Española de Derecho Constitucional, No 39, Madrid, (1993), pp. 81-113, p. 97.

${ }^{23}$ Similar, ARROYO ZAPATERO, Luis, "Principio de legalidad y reserva de ley en materia penal", Revista Española de Derecho Constitucional, No 8, Madrid, mayo - agosto (1983), pp. 9-46, p. 18; RUIZ ROBLEDO, Agustín, El derecho fundamental a la legalidad punitiva, Valencia: Tirant lo Blanch, 2003, p. 198. En contra, LASCURAÍN SÁNCHEZ, Juan Antonio, Sobre la retroactividad penal favorable, Madrid: Civitas, 2000, pp. 25 y 28. En la doctrina italiana, en contra de sostener que la retroactividad in bonam partem se deduzca del principio de legalidad penal, CADOPPI, Il principio di irretroattività, cit. nota $\mathrm{n}^{\mathrm{o}}$ 19, pp. 169 y ss. En el mismo sentido, en la doctrina chilena, BASCUÑ̂́N RODRÍGUEZ, Antonio, "La aplicación de la ley penal derogada", Revista del Abogado. Publicación del Colegio de Abogados de Chile, $\mathrm{N}^{\circ}$ 17, noviembre (1999), pp. 10-13, p. 11; EL MISMO, "La aplicación de la ley penal más favorable", Revista Jurídica de la Universidad de Puerto Rico, volumen 69, № 1, (2000), pp. $29-133$, p. 39.
} 
se promulguen sea para ellos una garantía, al menos, una que derive del principio de legalidad. $^{24}$

Por otra parte, no comparto la afirmación de Huerta Tocildo, en cuanto a considerar que la retroactividad de las leyes penales más benignas sea una derivación más del significado político y democrático del principio de legalidad. Generalmente, cuando los diversos autores explican cuál es el fundamento del principio de legalidad, suelen mencionar los siguientes: el liberalismo político, el principio de separación de poderes, el principio de culpabilidad y la prevención general. ${ }^{25}$ De éstos, los que más se vinculan con el sentido político y democrático del principio de legalidad son los dos primeros. Pero ninguno de ellos permite llegar a la conclusión de que la ley penal, cuando sea más favorable, deba ser retroactiva. El liberalismo político exige una vinculación de los poderes ejecutivo y judicial a las leyes. Esta idea se impuso merced a reivindicaciones de la burguesía, que reclamaba contra la arbitrariedad de los jueces y gobernantes, logrando con el tiempo que se reconociera la obligación de éstos de someterse a la ley, evitándose abusos de poder. Así se explican varias manifestaciones del principio de legalidad, como, por ejemplo, la proscripción de la analogía. Pero no se observa nada en el postulado del liberalismo político, consistente en exigir este apego a la ley, que obligue a dar aplicación retroactiva a las leyes penales más benignas. Incluso en un sistema en que rija una absoluta irretroactividad de todas las leyes penales, dicho modelo no se vería alterado. Y en cuanto al principio de división de poderes, éste exige, atendido que la pena constituye la más dura de las injerencias en la libertad de las personas, que su legitimación no resida en los jueces ni en el poder ejecutivo, sino en el Parlamento, órgano que representa al pueblo. Así se explica la exigencia de que sólo la ley pueda crear delitos y penas. Pero tampoco hay algo en esta idea que conduzca a la necesaria retroactividad de las leyes penales favorables. La división de poderes resultaría intacta si se estableciera un sistema de irretroactividad de toda ley penal. ${ }^{26}$

En otro orden de ideas, es verdad que los ciudadanos gozan de mayores espacios de libertad en sistemas que establecen la retroactividad de las leyes penales más favorables, que en aquellos que consagran la irretroactividad de toda ley penal, sea ésta benigna o severa. Y también es cierto que las exigencias que se suelen atribuir al principio de legalidad (prohibición de analogía, prohibición de Derecho consuetudinario para fundamentar o agravar la pena, prohibición de retroactividad y mandato de determinación) conducen a proteger la libertad de las personas. Pero no por eso se puede afirmar que la retroactividad in bonam partem sea una derivación del principio de legalidad penal. Ello, porque la protección de la libertad que se consigue con el principio de legalidad se dispensa como consecuencia de una evitación de intromisiones arbitrarias de la autoridad. En cambio, la mayor libertad que se logra con la aplicación

\footnotetext{
${ }^{24}$ Cfr. la argumentación, en el sentido del texto, de CUERDA RIEZU, "La aplicación retroactiva de las leyes favorables", cit. nota $\mathrm{n}^{\circ}$ 8, p. 290. Parecido, SINISCALCO, Marco, Irretroattività delle leggi in materia penale. Disposizioni sostanziali e disposizioni processuali nella disciplina della successione di leggi, Milán: Giuffrè, 1969, reimpresión 1987, p. 149.

${ }^{25}$ Así, ROXIN, Claus, Derecho Penal. Parte General, t. I, Trad. de la $2^{\mathrm{a}}$ edición alemana y notas, LUZÓN PEÑA, Diego Manuel et. al., Madrid: Civitas, 1997, pp. 144 y ss. Similar, BACIGALUPO, Enrique, Principios de Derecho Penal. Parte general, $5^{\text {a }}$ edición, Madrid: Akal, 1998, pp. 55 y ss.

${ }^{26}$ Cfr. JAKOBS, Gunther, Derecho Penal. Parte General. Fundamentos y teoría de la imputación, traducción de la $2^{\mathrm{a}}$ edición alemana de Joaquín Cuello Contreras y José Luis Serrano González de Murillo, Madrid: Marcial Pons, 1997: "Los problemas de la retroactividad de la ley [...] no son algo específico de la democracia" (p. 80); "en relación con la prohibición de retroactividad la división de poderes no indica nada" (p. 81).
} 
OLIVER, Guillermo. "Modificaciones en la regulación del delito de giro fraudulento de cheque: análisis desde la teoría de la sucesión de leyes".

retroactiva de las leyes penales más benignas, se obtiene a raíz de una prohibición de mantener penas innecesarias. ${ }^{27}$ A mayor abundamiento, es evidente que también se consiguen espacios de libertad a través de algunos de los denominados límites al ejercicio del ius puniendi, como, por ejemplo, el principio de exclusiva protección de bienes jurídicos, ${ }^{28}$ porque en la medida en que con la intervención penal no se incrimine cualquier conducta, sino que se castiguen sólo lesiones o puestas en peligro de intereses imprescindibles para el desarrollo de las personas en sociedad, más comportamientos podrán ser realizados sin correr el riesgo de sufrir la imposición de una pena. Y no por ello se puede sostener que también sean una derivación del principio de legalidad penal.

Bacigalupo sostiene que "vulnerar el principio de legalidad significa, precisamente, contradecir su fundamento" 29 , afirmación con la que estoy de acuerdo. Pues bien, en atención a que si se niega aplicación retroactiva a las leyes penales más favorables no se contraviene ninguno de los fundamentos del principio de legalidad penal, no puede verse en este principio el basamento de la retroactividad in bonam partem.

\subsection{Fundamentación compleja}

Es posible también encontrar en la doctrina opiniones que, buscando el fundamento de la aplicación retroactiva de las leyes penales más favorables, proponen una justificación compleja integrada por varias ideas. Así, por ejemplo, Luzón Peña afirma que

"el fundamento de la retroactividad de la ley más favorable responde principalmente al cambio de valoración jurídica en sentido desincriminador o atenuatorio que expresa la nueva ley, por lo que parece más justo [...] aplicarla también a los hechos anteriores, tratándolos igual que a los cometidos con posterioridad, y más adecuado, puesto que ya no parece necesario (a efectos preventivo-generales ni especiales) penar, o penar tanto, tales conductas [...]; además, tal retroactividad tiene un sentido humanitario o pietista, similar al de otras regulaciones o construcciones de orientación pro reo. Y aquí, a diferencia de lo que sucede cuando la nueva ley es desfavorable, no se opone a la retroactividad la posible infracción de las garantías para la seguridad jurídica por no aplicar la ley vigente durante el hecho". ${ }^{30}$

No comparto la opinión de quienes consideran que la retroactividad de las leyes penales más favorables tiene una justificación compleja, en la medida en que dentro de las

\footnotetext{
${ }^{27}$ La propia autora que critico en el texto no puede evitar aludir a consideraciones de necesidad de pena en su argumentación. Ver el destacado en cursiva de su opinión transcrita más arriba.

${ }^{28}$ Cfr., en relación con el principio de protección exclusiva de bienes jurídicos, entre otros, SILVA SÁNCHEZ, Aproximación, cit. nota n ${ }^{\circ}$ 13, pp. 267 y ss.; MIR PUIG, Derecho Penal. Parte General, cit. nota $\mathrm{n}^{\circ} 13$, pp. 128 y ss.; ZUGALDÍA ESPINAR, José Miguel, Fundamentos de derecho penal, $3^{\text {a }}$ edición, Valencia: Tirant lo Blanch, 1993, pp. 233 y ss.; BUSTOS RAMÍREZ, Juan, Manual de Derecho Penal. Parte General, $4^{a}$ edición aumentada, corregida y puesta al día por Hernán Hormazábal Malarée, Barcelona: PPU 1994, pp. 107 y ss.

${ }^{29}$ BACIGALUPO, Principios, cit. nota $\mathrm{n}^{\mathbf{0}} 25$, p. 57.

${ }^{30}$ LUZÓN PEÑA, Curso, cit. nota ${ }^{\circ} 5$, p. 183 (las cursivas en el original). Cfr. también SÁINZ CANTERO, Lecciones, cit. nota $\mathrm{n}^{\circ} 5$, pp. 398 y s., aludiendo a consideraciones humanitarias y de justicia; ANTÓN ONECA, Derecho Penal, cit. nota $\mathrm{n}^{\circ}$ 5, pp. 126 y s., mencionando razones de humanidad, justicia y fines de defensa social; SERRANO BUTRAGUEÑO, Retroactividad, cit. nota $\mathrm{n}^{\circ} 5$, p. 2 , señalando motivos de justicia, necesidad de pena y de humanidad; PÉREZ ROYO, La aplicación retroactiva, cit. nota $\mathrm{n}^{\mathrm{o}} 17$, pp. 78 y s., invocando los principios de intervención mínima, prohibición de exceso e igualdad ante la ley.
} 
varias razones que suelen mencionarse como fundamento, se incluyen ideas que ya he rechazado. ${ }^{31}$ En efecto, los autores que proponen una fundamentación compuesta insertan en ella, entre otras explicaciones, consideraciones de justicia, motivos humanitarios o de piedad, fines de defensa social y exigencias derivadas del principio de igualdad ante la ley, ideas todas que no comparto por las razones más arriba esgrimidas. Por otra parte, la pretensión de asignar varios fundamentos a la retroactividad de las leyes penales más benignas plantea el problema de determinar qué sucede cuando, en un caso concreto, algunos de los basamentos asignados concurren y otros no. En tanto quienes atribuyen a la retroactividad in bonam partem un fundamento múltiple no aportan criterios para decidir cuál de los varios basamentos debe tener preponderancia sobre los otros en caso de antinomia, no resulta posible contar con una herramienta eficaz para determinar en todos los casos si debe o no darse aplicación retroactiva a una ley penal favorable, razón por la cual esta corriente doctrinal debe ser rechazada. ${ }^{32}$

\subsection{Tesis funcionalista}

Podría alguien plantear que el fundamento de la retroactividad in bonam partem se encuentra en consideraciones de orden funcionalista, cuestión que rechazaría. Si se sostiene que en la construcción del sistema penal no existen más límites que los que emanan de su funcionalidad o eficacia, no habría problemas en negar la aplicación retroactiva de las leyes penales favorables, si esto resultara funcional para la eficacia de dicho sistema. No puede, entonces, un planteamiento funcionalista servir de basamento del principio de retroactividad de las leyes penales más benignas, porque puede conducir a la destrucción del mismo principio que pretende fundar.

Por otra parte, debe tenerse presente que existen grandes diferencias entre las legislaciones de los diversos países en la configuración de este principio. Por ejemplo, mientras en unos la existencia de una condena firme es un impedimento para su operatividad, en otros no representa obstáculo alguno. Una tesis funcionalista no criticaría ninguno de los dos sistemas, sino que se limitaría a describirlos y a afirmar que ambos se encuentran estructurados de manera eficaz para su autoconservación. Ello me parecería insatisfactorio. La determinación del fundamento material de la retroactividad in bonam partem, además de ser útil para determinar su alcance, es necesaria para criticar su configuración en el sistema penal de cualquier país, labor que la dogmática, en mi opinión, no puede soslayar.

\subsection{Principio de proporcionalidad en sentido amplio o prohibición de exceso}

Finalmente, hay autores que sostienen que el fundamento de la retroactividad de las leyes penales más favorables se encuentra en el denominado principio de proporcionalidad en sentido amplio o prohibición de exceso. Es el caso, verbigracia, de Silva Sánchez, quien afirma que

\footnotetext{
${ }^{31}$ Hago salvedad de las consideraciones de necesidad a las que Luzón Peña alude. Sobre la virtualidad justificadora de la retroactividad in bonam partem que en tales consideraciones puede verse, me pronuncio más abajo.

${ }^{32}$ Cfr. RAGUÉS I VALLÈS, Ramón, La prescripción penal. Fundamento y aplicación. Texto adaptado a la LO 15/2003 de reforma del Código penal, Barcelona: Atelier, 2004, pp. 40 y ss., cuya argumentación para oponerse a la pretensión de asignar un fundamento múltiple a la figura de la prescripción, recojo en el texto.
} 
OLIVER, Guillermo. "Modificaciones en la regulación del delito de giro fraudulento de cheque: análisis desde la teoría de la sucesión de leyes".

"el principio general de irretroactividad de las leyes penales cuenta con una significativa excepción. Se trata de la admisibilidad de la aplicación retroactiva de las disposiciones favorables al reo, cuyo fundamento reside en razones políticocriminales que Cobo y Vives, por ejemplo, con acierto [...] reconducen a las exigencias del principio de prohibición de exceso". ${ }^{33}$

En mi opinión, están en lo correcto quienes señalan que es el principio de proporcionalidad en sentido amplio o prohibición de exceso el fundamento de la aplicación retroactiva de las leyes penales más benignas. La siguiente argumentación pretende ser una demostración de ello. ${ }^{34}$

${ }^{33}$ SILVA SÁNCHEZ, "Legislación penal socio-económica", cit. nota no 3, p. 699 (las cursivas son mías). Cfr. también COBO DEL ROSAL / VIVES ANTÓN, Derecho Penal. Parte General, cit. nota no 13 , pp. 195 y s.; LOS MISMOS, "Comentario al art. 2 del Código Penal" en: COBO DEL ROSAL (dir.), Comentarios al Código Penal, t. I, Madrid: Edersa, 1999, pp. 69-86, p. 73; LOS MISMOS, "Retroactividad de las disposiciones favorables en materia de contrabando" en: COBO DEL ROSAL, Manuel (dir.); BAJO FERNÁNDEZ, Miguel (coord.), Comentarios a la Legislación Penal, t. III, Madrid: Edersa, 1984, Delitos e infracciones de contrabando, pp. 583-585, p. 585; GÓRRIZ ROYO, Elena, "La problemática de las remisiones normativas y de la retroactividad de las leyes penales favorables en relación a los delitos sobre la ordenación del territorio", Revista de Ciencias Penales, volumen $1, \mathrm{n}^{\circ} 1$, (1998), pp. 73-99, p. 90; PÉREZ ROYO, "La aplicación retroactiva", cit. nota no 17, pp. 78 y s., sin que el principio de prohibición de exceso sea para este autor el único fundamento de la retroactividad in bonam partem; GONZÁLEZ TAPIA, Determinación del tiempo, cit. nota $\mathrm{n}^{\circ}$ 17, pp. 202 y ss.; FRÍGOLS I BRINES, Fundamentos, cit. nota $\mathrm{n}^{\circ} 3$, pp. 410 y ss. Similar, haciendo referencia al principio de proporcionalidad, LASCURAÍN SÁNCHEZ, Sobre la retroactividad penal favorable, cit. nota $\mathrm{n}^{\circ} 23$, pp. 31 y ss.; EL MISMO, "Delito fiscal y retroactividad" en: MIR PUIG, Santiago et al, Estudios de Derecho Penal Económico, Caracas: Livtosca, 2002, pp. 433-469, pp. 435 y ss. Parecido, pero aludiendo al principio de necesidad de pena, MIR PUIG, Derecho Penal. Parte General, cit. nota ${ }^{\circ} 13$, p. 116; BUSTOS RAMÍREZ, Manual de Derecho Penal. Parte General, cit. nota no 28, pp. 176 y s.; BUSTOS RAMÍREZ, Juan; HORMAZÁBAL MALARÉE, Hernán, Lecciones de derecho penal, vol. I, Madrid: Trotta, 1997, p. 107; CARBONELl MATEU, Juan Carlo, Derecho penal: concepto y principios constitucionales, $3^{\text {a }}$ edición, Valencia: Tirant lo Blanch, 1999, pp. 140 y ss.; RUIZ DE ERENCHUM, "El 'sistema de sucesión de leyes"', cit. nota n ${ }^{\circ}$ 5, pp. 331 y 384; MARTÍNEZ-BUJÁN PÉREZ, Carlos, Derecho Penal Económico. Parte General, Valencia: Tirant lo Blanch, 1998, pp. 127 y ss.; EL MISMO, Los delitos contra la hacienda pública y la seguridad social, Madrid: Tecnos, 1995, pp. 121 y ss. Cfr. también FIORE, De la irretroactividad e interpretación de las leyes, cit. nota $\mathrm{n}^{\circ} 4$, p. 442 , quien no obstante sostener que el fundamento de la retroactividad de las leyes penales favorables se encuentra en la idea de justicia, agrega un argumento de proporcionalidad "entre la contravención realizada o la violación de la ley, con el mal que se reconozca por el legislador como necesario y eficaz para restablecer el orden jurídico", añadiendo que "sería arbitrario fijar una pena exorbitante, o sea, superior a lo que pueda ser exigido, con arreglo a la razón penal, para conseguir el fin racional de la pena, es decir, la tutela del orden jurídico". En la doctrina alemana, cfr. JAKOBS, Derecho Penal. Parte General, cit. nota n 26, p. 112, aludiendo a la evitación de penas innecesarias. En la doctrina peruana, alude al principio de prohibición de exceso PEÑA CABRERA, Raúl, Tratado de Derecho Penal. Estudio programático de la parte general, $3^{\text {a }}$ edición corregida y aumentada con la colaboración de Carlos Atocsa García, José A. Caro John, Reiner Chocano Rodríguez y Sofía Laqui Pizarro, Lima: Grijley, 1997, reimpresión de 1999, p. 236. En la doctrina argentina, haciendo referencia a la necesidad de pena, FIERRO, Guillermo, "Los delitos permanentes y la ley más benigna", Jurisprudencia Argentina, Buenos Aires, 2000, tomo IV, p. 575; YMAZ VIDELA, Martín Rafael, "La sucesión de leyes penales: el artículo 24 de la ley 24.769 y la derogación de la ley 23.771", El Derecho, No 176, Buenos Aires, (1998), pp. 1003-1010, p. 1006. En la doctrina chilena, aludiendo a la prohibición de exceso, cfr. BASCUÑÁN RODRÍGUEZ, Antonio, "La ley penal", Comentario de la jurisprudencia del año 2003 de la Corte Suprema y del Tribunal Constitucional. Revista de Derecho de la Universidad Adolfo Ibánez, No 1, (2004), pp. 209-227, p. 212; EL MISMO, "La aplicación de la ley penal derogada", cit. nota ${ }^{\circ} 23$, p. 11.

${ }^{34}$ Cfr. SILVA SÁNCHEZ, "Legislación penal socio-económica", cit. nota no 3, pp. 699 y s., cuya argumentación recojo para el análisis que sigue en el texto. 
Lo primero que hay que tener presente es que tres son las exigencias que se suelen reconocer dentro del llamado principio de proporcionalidad en sentido amplio o prohibición de exceso: idoneidad o adecuación a fin, es decir, que la intervención penal sirva para proteger bienes jurídicos a través de la prevención general y especial de delitos que los lesionen o pongan en peligro; necesidad, esto es, que dicha intervención no vaya más allá de lo indispensable para alcanzar el fin que se persigue, causando el menor daño posible, y proporcionalidad en sentido estricto, o sea, que exista una armónica relación entre la gravedad y la nocividad social del delito y la gravedad de la sanción penal. $^{35}$

Pues bien, si se promulga una ley que convierte en impune un hecho que antes era punible, la pena impuesta por el mismo hecho -o que se pretenda imponer- conforme a la anterior ley ya no cumpliría ningún efecto de prevención general ni especial. ${ }^{36}$ En tal caso, no aplicar retroactivamente la nueva ley supondría infringir el principio de proporcionalidad en sentido amplio o prohibición de exceso, porque se mantendría -o se impondría- una pena que no sería idónea para el fin de prevención de delitos, ni necesaria para el mismo fin, ni estrictamente proporcionada. En efecto, si cualquier ciudadano realizara el mismo hecho a futuro, no tendría sanción (punto de vista de la prevención general), lo mismo que si lo repitiera quien lo había realizado bajo la vigencia de la ley anterior ${ }^{37}$ (punto de vista de la prevención especial). Luego, al no ser la pena anterior -o la que se quiera imponer según la ley anterior-idónea para prevenir delitos, tampoco será necesaria para ese fin, atendido que la exigencia de necesidad de la intervención penal parte de la base de que ésta sirva al fin de prevención de delitos. En consecuencia, tampoco será estrictamente proporcionada, toda vez que la proporcionalidad en sentido estricto obliga a tomar en cuenta la gravedad del delito o la nocividad social del hecho, y en este caso el hecho por el que se mantendría la pena ya impuesta -o por el que se impondría la pena-, según la nueva valoración social, ya no sería delito ni tendría una nocividad tal que justifique la intervención penal. En síntesis,

${ }^{35}$ Así, COBO DEL ROSAL / VIVES ANTÓN, Derecho Penal. Parte General, cit. nota no 13, pp. 84 y ss.; AGUADO CORREA, Teresa, El principio de proporcionalidad en derecho penal, Madrid: Edersa, 1999, pp. 149 y ss.; CUERDA ARNAU, María Luisa, "Aproximación al principio de proporcionalidad en derecho penal” en: GONZÁLEZ CUSSAC, José Luis et al, Estudios jurídicos en memoria del profesor Dr. D. José Ramón Casabó Ruiz, vol. I, Valencia: Universidad de Valencia. Instituto de Criminología, 1997, pp. 447-491, pp. 468 y ss. En la doctrina argentina, desde un punto de vista filosófico jurídico, cfr. CIANCIARDO, Juan, El principio de razonabilidad. Del debido proceso sustantivo al moderno juicio de proporcionalidad, Buenos Aires: Editorial Ábaco de Rodolfo Depalma, 2004, pp. 61 y ss. En la doctrina colombiana, VELÁSQUEZ VELÁSQUEZ, Fernando, "El principio de prohibición de exceso en el Código penal colombiano" en: DE FIGUEIREDO DIAS, Jorge; SERRANO GÓMEZ, Alfonso; POLITOFF LIFSCHITZ, Sergio; ZAFFARONI, Eugenio Raúl (dirs.); GUZMÁN DÁLBORA, José Luis, El penalista liberal. Controversias nacionales e internacionales en derecho penal, procesal penal y criminología. Homenaje a Manuel de Rivacoba y Rivacoba, Buenos Aires: Hammurabi, 2004, pp. 363-391, pp. 371 y ss. En la doctrina chilena, cfr. BORDALÍ SALAMANCA, Andrés, "Temas de derecho procesal constitucional", Fallos del mes, Valdivia, (2003), pp. 68 y ss.; BASCUÑ̂́N RODRÍGUEZ, Antonio, "Delitos contra intereses instrumentales", Comentario de la jurisprudencia del año 2003 de la Corte Suprema y del Tribunal Constitucional. Revista de Derecho de la Universidad Adolfo Ibáñez, $\mathrm{n}^{\circ} 1$, (2004), pp. 291-345, p. 323.

${ }^{36}$ Sobre la ausencia de tutela de bienes jurídicos -a través de la prevención de delitos que los lesionen o pongan en peligro- que en este caso se produciría, llama la atención MUSCO, Mauricio, La riformulazione dei reati. Profili di diritto intertemporale, Milán: Giuffrè, 2000, pp. 20 y ss. Similar, GROUBER, Alexandre, Du conflit des lois d'incrimination et de pénalité dans le temps, París: Rousseau et Cie., 1915, pp. 114 y ss., 232.

37 Ver CADOPPI, Il principio di irretroattività, cit. nota $\mathrm{n}^{\mathrm{o}} 19$, pp. 172 y ss., destacando que la inaplicación retroactiva de una ley despenalizadora no serviría para cumplir fines de reeducación del reo. 
OLIVER, Guillermo. "Modificaciones en la regulación del delito de giro fraudulento de cheque: análisis desde la teoría de la sucesión de leyes".

no aplicar retroactivamente una nueva ley más favorable que convierte en impune un hecho antes punible importaría permitir una falta de idoneidad de la intervención penal, lo que, a su vez, provocaría una ausencia de necesidad y de proporcionalidad en sentido estricto de la misma.

Si se promulga una ley que reduce la penalidad de un hecho, su inaplicación retroactiva también produciría una evidente vulneración del principio de proporcionalidad en sentido amplio o prohibición de exceso, pero por otras razones. En efecto, tal inaplicación importaría mantener -o imponer- una pena que, siendo idónea para el fin de prevenir delitos, no sería necesaria en aquella medida que excediera de la cuantía aplicable según la nueva ley. ${ }^{38} \mathrm{Si}$ la necesidad de la intervención penal consiste en que ésta no vaya más allá de lo indispensable para alcanzar el fin de prevención de delitos, causando el menor daño posible, entonces en el exceso la pena impuesta -o que se pretenda imponer- conforme a la ley anterior se mostraría innecesaria. Y, por lo tanto, el mantenimiento -o la imposición- de la misma tampoco serían estrictamente proporcionados, de acuerdo con la nueva valoración social, según la cual para la gravedad del delito y la nocividad social del hecho basta la cuantía de pena contemplada en la nueva ley. En suma, no aplicar retroactivamente una nueva ley más favorable que reduce la penalidad de un hecho importaría permitir una intervención penal que, cumpliendo la exigencia de idoneidad de la misma, no satisfaría la exigencia de necesidad, lo que, a su vez, se traduciría en una infracción a la proporcionalidad en sentido estricto.

\section{Retroactividad de las modificaciones procesales favorables}

Un examen de la doctrina permite constatar que en torno al problema de determinar si la retroactividad in bonam partem alcanza o no a las modificaciones favorables a los reos en disposiciones procesales, existen dos posiciones. ${ }^{39}$ Algunos se oponen a dicha extensión, sosteniendo, básicamente, que el efecto retroactivo es predicable sólo para las leyes penales sustantivas. Es el caso, por ejemplo, en la doctrina española, de Luzón Peña, quien afirma que

las disposiciones procesales, "como normas no penales, no se rigen por las reglas de [...] retroactividad de los arts. [...] 2.1 y 2 CP 1995, sino en principio por la regla del art. $2.3 \mathrm{CC}$, es decir, que en general no serán retroactivas, pero pueden disponer lo contrario". ${ }^{40}$

\footnotetext{
${ }^{38}$ Cfr. MUSCO, La riformulazione dei reati, cit. nota $\mathrm{n}^{\circ} 36$, p. 22, advirtiendo una relación entre la aplicación retroactiva de una ley de esta clase y el principio de subsidiariedad, que ve en el recurso a la sanción penal una herramienta de última ratio. Ver TAIPA DE CARVALHO, Sucessão de leis penais, cit. nota $\mathrm{n}^{\circ} 19$, pp. 70 y s.: "se o legislador entende que uma pena menos grave e, portanto, menos limitadora dos direitos fundamentais, máxima da liberdade, é suficiente para realizar as funções político-criminais de prevenção geral (de integração e de intimidação) e de prevenção especial (também de integração e de intimidação do delinquente), então esta terá de aplicar-se retroactivamente. $O$ contrário seria aplicar uma pena que, no momento da aplicação (ou mesmo da execução), é tida como desnecessária e, portanto, seria inconstitucional".

${ }^{39}$ Sobre el punto, véase OLIVER CALDERÓN, Retroactividad, cit. nota $\mathrm{n}^{\circ} 1$, pp. 379 y ss.

${ }^{40}$ LUZÓN PEÑA, Curso, cit. nota n ${ }^{\circ}$ 5, p. 193 (las cursivas son mías). En el mismo sentido, QUINTERO OLIVARES, Gonzalo; MORALES PRATS, Fermín; PRATS CANUT, Josep, Manual de Derecho Penal. Parte General, $3^{\mathrm{a}}$ edición, Navarra: Aranzandi, 2002, p. 174; CUERDA RIEZU, Antonio, "Irretroactividad y retroactividad de la ley penal", en: Enciclopedia Jurídica Básica, vol. III, Madrid: Civitas, 1995, pp. 3769-3771, p. 3770. En la doctrina italiana, ROMANO, Mario, Commentario sistemático del Codice Penale, vol. I, 2ª edición, Milán: Giuffrè, 1995, p. 59.
} 
Otros se declaran partidarios de tal extensión, otorgando un carácter amplio a la benignidad de la ley a aplicar retroactivamente. Así, verbigracia, en la doctrina argentina, Zaffaroni / Alagia / Slokar señalan que

dicha favorabilidad no sólo puede tener su origen en la desincriminación de un hecho o el establecimiento de una pena menor, sino que "puede provenir también de otras circunstancias, como [...] las consecuencias procesales".

En mi opinión, es necesario distinguir, por un lado, los casos en los que la modificación favorable en la legislación procesal penal puede dar lugar a una verdadera aplicación retroactiva y, por otro, los casos en los que tal modificación sólo origina una aplicación inmediata, in actum, como se explica enseguida.

\subsection{Modificaciones procesales favorables y aplicación in actum}

Si la ley procesal penal más benigna se promulga cuando aún no se ha iniciado un proceso para juzgar hechos realizados con anterioridad a su entrada en vigor, deberá ser aplicada en su juzgamiento, de conformidad con el brocardo tempus regit actum. Por ejemplo, si a la época de la perpetración de un delito la normativa procesal lo contempla como uno de los que hacen procedente la medida cautelar de prisión preventiva y antes de que se inicie el proceso opera un cambio en tal regulación, que lo excluye del listado de delitos que hacen procedente dicha medida cautelar, no se la podrá decretar en el posterior proceso que para juzgar el delito se inicie. De este modo, la modificación producirá sus efectos in actum, sin tener aplicación verdaderamente retroactiva, toda vez que su objeto de regulación -el proceso- aún no existe.

Un breve examen que tome en cuenta el principio de proporcionalidad en sentido amplio o prohibición de exceso revela que en un caso como éste -cambio procesal penal benigno antes del comienzo del proceso-, la aplicación in actum resulta obligatoria. En efecto, dicho principio opera como límite no sólo en la imposición de consecuencias jurídico-penales (penas y medidas de seguridad), sino también en el desarrollo del procedimiento que culminará con tal imposición. ${ }^{42}$ Carece de sentido reservar los

41 ZAFFARONI, Eugenio Raúl; ALAGIA, Alejandro; SLOKAR, Alejandro, Derecho Penal. Parte General, $2^{\text {a }}$ edición, Buenos Aires: Ediar, 2003, p. 121. Ver también JIMÉNEZ DE ASÚA, Luis, Tratado de derecho penal, t. II, $5^{\text {a }}$ edición, Buenos Aires: Losada, 1950, p. 628, extendiendo la retroactividad a los cambios favorables en la normativa procesal penal. En la doctrina italiana proponen también esta extensión GALLO, Marcello, "Interpretazione della Corte costituzionale e interpretazione giudiziaria (a proposito delle garanzie della difesa nell'istruzione sommaria)", Rivista Italiana di Diritto e Procedura Penale, (1965), pp. 200-216, p. 216; CARNELUTTI, Francesco, "Riflessioni sulla successione di leggi penali processuali” en: EL MISMO, Questioni sul processo penale, Bolonia: Cesare Zuffi, 1950, pp. 187200, pp. 194 y ss. En la doctrina belga, RUBBRECHT / DECLERCQ, "La non-rétroactivité", cit. nota n 11, p. 216, proclamando la fuerza retroactiva de las leyes de procedimiento que restringen la posibilidad de perseguir al imputado y de aplicarle una pena. En la doctrina portuguesa, TAIPA DE CARVALHO, Sucessão de leis penais, cit. nota $\mathrm{n}^{\circ} 19$, pp. 212 y ss.

${ }^{42}$ Cfr. GONZÁLEZ-CUÉLLAR SERRANO, Nicolás, Proporcionalidad y derechos fundamentales en el proceso penal, Madrid: Colex, 1990, p. 17; ARMENTA DEU, Teresa, Lecciones de Derecho Procesal Penal, $2^{\text {a }}$ edición, Madrid: Marcial Pons, 2004, pp. 70 y ss.; ASENCIO MELLADO, José María, Derecho Procesal Penal, $3^{\mathrm{a}}$ edición, Valencia: Tirant lo Blanch, 2004, pp. 139 y ss.; DE LA OLIVA SANTOS, Andrés; ARAGONESES MARTÍNEZ, Sara; HINOJOSA SEGOVIA, Rafael; MUERZA ESPARZA, Julio; TOMÉ GARCÍA, José Antonio, Derecho Procesal Penal, $7^{\text {a }}$ edición, Madrid: Editorial Universitaria Ramón Areces, 2004, pp. 402 y ss.; SANGUINÉ, Odone, Prisión provisional y derechos 
OLIVER, Guillermo. "Modificaciones en la regulación del delito de giro fraudulento de cheque: análisis desde la teoría de la sucesión de leyes".

subprincipios que de la prohibición de exceso emanan para la concreta aplicación de tales consecuencias, y no exigir también su cumplimiento para el proceso penal. Máxime, cuando en el transcurso del proceso el Estado se vale de medios para asegurar la eficacia de las eventuales consecuencias jurídico-penales que pueda imponer a futuro contra el imputado, que pueden resultar tanto o más aflictivos que éstas, como la prisión preventiva. En el ejemplo, según la nueva valoración social, para asegurar la eficacia de las consecuencias jurídico-penales que se puedan imponer a las personas a quienes se impute el delito de que se trata, basta cualquier medida cautelar menos gravosa que la prisión preventiva. Luego, si en los futuros procesos que se incoen por delitos de la misma naturaleza cometidos antes de la nueva ley se decreta la prisión preventiva, se estará sometiendo a los imputados a un ejercicio del ius puniendi que, pudiendo ser idóneo para garantizar la eficacia de las eventuales sanciones que se puedan imponer, no será necesario, en aquella parte en que sobrepase la aflictividad de las medidas cautelares imponibles según la ley nueva. ${ }^{43}$ Por lo tanto, en esta parte tampoco será estrictamente proporcionado, según las nuevas valoraciones sociales, y por ende, constituirá una violencia estatal excesiva.

Lo dicho tiene validez no sólo para los casos en los que antes del proceso tiene lugar una modificación favorable en disposiciones cuya naturaleza procesal no se discute, sino también para los casos en los que el cambio recae sobre disposiciones cuya naturaleza procesal o penal es objeto de discusión, como por ejemplo, la exigencia de denuncia o querella previa para el inicio del procedimiento. Verbigracia, si al tiempo de comisión de un delito la legislación procesal lo consideraba de acción penal pública y una posterior modificación lo convierte en uno de acción privada o de acción pública previa instancia particular, no podrá comenzar el proceso sin que se deduzca una querella o se formule una denuncia. Esta modificación surtirá efectos in actum, pero no podría hablarse en este caso de una aplicación verdaderamente retroactiva, porque el proceso aún no existe. ${ }^{44}$

fundamentales, Valencia: Tirant lo Blanch, 2003, pp. 638 y ss., concretamente en relación con la medida cautelar de prisión preventiva.

${ }^{43}$ GONZÁLEZ-CUÉLLAR SERRANO, Proporcionalidad y derechos fundamentales, cit. nota $n^{\circ} 42$, pp. 197 y s.: "Es obvio que el peligro de fuga que trata de evitar la prisión provisional disminuye en mayor medida mediante el ingreso del imputado en un establecimiento penitenciario que mediante la adopción de otras medidas sustitutivas de la prisión provisional, como la libertad bajo caución. Pero si se prevé que la medida alternativa será suficientemente eficaz para evitar el peligro de fuga, dadas las circunstancias del caso, es no sólo legítimo, sino constitucionalmente preciso, el sacrificio de la mayor seguridad que proporciona la medida más gravosa, que es la prisión, en beneficio del valor libertad".

${ }^{44}$ Sin distinguir entre aplicación inmediata y aplicación retroactiva, se inclinan por la "retroactividad" de las modificaciones legales que conviertan un delito perseguible de oficio en uno perseguible previa denuncia o querella, entre otros, SÁINZ CANTERO, Lecciones de Derecho Penal, cit. nota $\mathrm{n}^{\circ}$ 5, p. 402; MORILLAS CUEVA, Derecho Penal. Parte Genera, cit. nota n ${ }^{\circ}$, p. 226; MORILLAS CUEVA / RUIZ ANTÓN, Manual de Derecho Penal, cit. nota $\mathrm{n}^{\circ}$ 7, pp. 88 y ss. En la doctrina alemana, MEZGER, Edmund, Tratado de derecho penal, t. I, trad. de la $2^{\mathrm{a}}$ edición alemana de RODRÍGUEZ MUÑOZ, José Arturo, con notas, Madrid, 1946, p. 130. En la doctrina francesa, RASSAT, Michèle-Laure, Droit pénal, París: Presses Universitaires de France, 1987, pp. 206 y ss.; ROUBIER, Le Droit Transitoire, cit. nota $\mathrm{n}^{\circ}$ 7, p. 522. En la doctrina italiana, FIORE, Carlo, Diritto Penale. Parte Generale, t. I, Turín: UTET, 1993, p. 89; PULITANÒ, “Commentario al articolo 2", cit. nota $\mathrm{n}^{\mathbf{0}} 17$, p. 20. En la doctrina colombiana, GÓMEZ LÓPEZ, Jesús Orlando, Tratado de derecho penal. Parte general, t. I, Bogotá: Doctrina y ley, 2001, p. 844; JIMÉNEZ RODRÍGUEZ, J. Héctor, "Límites temporales de la ley penal: aspectos sustanciales y procesales", Temas de Derecho Penal Colombiano, no 14, Medellín, (1981), pp. 33-45, p. 40. En la doctrina brasileña, DUARTE, “A lei penal no tempo”, cit. nota no 10, pp. 628 y ss. En la doctrina peruana, HURTADO POZO, José, Manual de Derecho Penal. Parte general, $2^{\text {a }}$ edición, Lima: Eddili, 1987, p. 300. En la doctrina argentina, la decisión de reconocer o no efecto retroactivo a estas 
Un análisis a partir del principio de proporcionalidad en sentido amplio o prohibición de exceso también demuestra que en un caso como el recién planteado, la aplicación inmediata resulta obligatoria. En efecto, iniciar un proceso penal por un delito anterior a la modificación, si no se ha deducido denuncia o querella alguna, implicaría poner en marcha el aparato de persecución penal sin que exista necesidad de ello, de acuerdo con las valoraciones sociales actuales. Como es sabido, en íntima vinculación con la exigencia de subsidiariedad, que integra el principio de necesidad, el que a su vez se deriva -junto con el de idoneidad y el de proporcionalidad en sentido estricto- de la prohibición de exceso, se encuentra la idea de necesidad de pena. Esta idea obliga a efectuar un análisis de utilidad social en la evaluación de lo satisfactorio que resulta la intervención penal. Tal intervención sería insatisfactoria si generara efectos accesorios que se estimasen negativos o si los objetos de protección pudieran ser tutelados por medios menos lesivos. Pues bien, en mi ejemplo, según la nueva valoración social, la intervención penal sólo resultaría satisfactoria si el ofendido por el delito estuviera de acuerdo con que ésta se lleve adelante y manifestara su conformidad por medio de una denuncia o de una querella. Podría no estarlo, porque el hecho no le parece tan grave, porque no quiere que se sepa que fue víctima de un delito, porque quiere evitar una victimización secundaria o por otras razones. Para la valoración social actual estas razones se estiman valiosas y se producirían efectos accesorios negativos si no se atendieran. Por ello, cualesquiera fueren los motivos por los que el ofendido no esté de acuerdo en el inicio de un proceso, llevar adelante la intervención penal e imponer una pena sin que haya deducido denuncia ni querella, implicaría no respetar la exigencia de necesidad de pena. Se llegaría así a la imposición de una pena que se revelaría innecesaria y, por ende, desproporcionada.

\subsection{Modificaciones procesales favorables y retroactividad}

Si la ley procesal penal más favorable al imputado se dicta una vez que el proceso se ha iniciado, como su objeto de regulación ya existe, sí podría hablarse de retroactividad, en la medida que se aplique a actos procesales anteriores. Para los actos procesales posteriores se deberá aplicar de inmediato, por mandato del aforismo tempus regit actum.

A mi juicio, en los supuestos en los que la ley procesal penal más benigna puede dar lugar a una verdadera aplicación retroactiva, tal retroactividad resulta obligatoria, también por aplicación del principio de proporcionalidad en sentido amplio o

modificaciones se hace depender de la naturaleza que se asigne a las disposiciones que condicionan el ejercicio de la acción penal. Para la mayoría de los autores argentinos tienen naturaleza penal, por lo que procedería su aplicación retroactiva si son favorables. En este sector doctrinal, ver KILIBARDA, Danilo, "La ley penal más benigna y el delito de lesiones leves", Revista Jurídica Argentina La Ley, n 135, Buenos Aires, julio - septiembre (1969), pp. 145-149, pp. 145 y ss. Para un sector minoritario tienen carácter procesal, por lo que no procedería su retroactividad. En este sector doctrinal, ver RIVAS GODIO, Luis Enrique, "La iniciativa privada en las lesiones leves y el procedimiento penal intertemporal: ámbito de validez temporal de la nueva ley penal", Revista Jurídica Argentina La Ley, n 130, Buenos Aires, abril - junio (1968), pp. 1147-1153, pp. 1147 y ss. Para BIDART CAMPOS, Germán J., "La irretroactividad de la ley penal y el principio de la ley más benigna", Revista de Derecho penal y Criminología, Buenos Aires: (1970), pp. 333-345, p. 340, con independencia de su naturaleza sustantiva o adjetiva, si son favorables se deben aplicar retroactivamente. Sobre la discusión doctrinal argentina acerca de este tema ver FIERRO, Guillermo, La ley penal y el derecho transitorio. Retroactividad e irretroactividad, Buenos Aires: Depalma, 1978, pp. 281 y ss. 
OLIVER, Guillermo. "Modificaciones en la regulación del delito de giro fraudulento de cheque: análisis desde la teoría de la sucesión de leyes".

prohibición de exceso. ${ }^{45}$ Imaginemos, por ejemplo, que bajo la vigencia de la ley procesal más severa se decreta la prisión preventiva de Juan, y cuando lleva un año sujeto a dicha medida cautelar se promulga una nueva ley procesal que rebaja el plazo máximo de duración de la misma a seis meses para el delito que se le imputa. En tal evento, negar aplicación retroactiva a la nueva ley y no conceder la libertad a Juan, importará un ejercicio de la potestad penal del Estado revestido de una violencia innecesaria. En efecto, tal como ya lo señalé, la prohibición de exceso no sólo representa un límite para la imposición de consecuencias jurídico-penales, sino también para el inicio y desarrollo del proceso. Más aún, cuando en el transcurso de éste el Estado se vale de medios altamente lesivos para los derechos de las personas, como la prisión preventiva. En mi ejemplo, según las nuevas valoraciones sociales, para asegurar la eficacia de las consecuencias jurídico-penales que se puedan imponer a las personas a quienes se impute el mismo delito que a Juan, basta una medida cautelar de prisión preventiva que no exceda de seis meses. En consecuencia, si a Juan no se le aplica la ley nueva y no se le concede la libertad, se le estará sometiendo a un ejercicio del ius puniendi que, pudiendo ser idóneo para garantizar la eficacia de las eventuales sanciones que se puedan imponer, no será necesario, en aquella parte en que sobrepase la aflictividad de la medida cautelar imponible según la nueva ley. Luego en esta parte tampoco será estrictamente proporcionado, según las nuevas valoraciones sociales, y por ende, constituirá un exceso. ${ }^{46}$

Lo mismo puede decirse cuando, con posterioridad al inicio del proceso, tiene lugar una modificación favorable al imputado en disposiciones cuya naturaleza procesal o penal es discutida, como por ejemplo, las que exigen la interposición de denuncia o querella previa. Si una vez incoado un proceso para juzgar un delito que al tiempo de su comisión era perseguible de oficio, cambia la legislación para exigir que sólo pueda juzgarse tal delito previa querella del ofendido, o al menos previa denuncia, resulta obligatorio, por mandato del principio de prohibición de exceso, aplicar la modificación si en el proceso no ha habido denuncia ni querella de la víctima, retrotrayendo el procedimiento al momento anterior a su inicio y esperando la eventual interposición de denuncia o querella. ${ }^{47}$ No hacerlo así y seguir adelante hasta la imposición de una

\footnotetext{
${ }^{45}$ Cfr. PISAPIA, G. Domenico, "Impugnabilità del mandato di cattura e successione di leggi processuali”, Rivista Italiana di Diritto Penale, (1957), pp. 50-59, pp. 50 y ss., sosteniendo -sin aludir explícitamente al principio de proporcionalidad-, a partir de una modificación habida en el Codice di Procedura Penale italiano, la retroactividad de cambios favorables en la legislación procesal penal que amplían los recursos contra las órdenes de detención.

${ }^{46}$ Llega a una conclusión similar TAIPA DE CARVALHO, Sucessão de leis penais, cit. nota ${ }^{\circ}$ 19, pp. 247 y ss.

En Argentina se ha discutido la naturaleza procesal o penal de la prisión preventiva y de ello se ha hecho depender la decisión de dar o no efecto retroactivo a las modificaciones favorables en su regulación. Según BIDART CAMPOS, "La irretroactividad de la ley penal", cit. nota $\mathrm{n}^{\circ}$ 44, p. 341, aun admitiendo la índole procesal de las leyes sobre excarcelación, debe operar la retroactividad in bonam partem. Cfr. FIERRO, Legalidad y retroactividad de las normas penales, cit. nota $\mathrm{n}^{\mathrm{o}} 7$, pp. 319 y s.

${ }^{47}$ Similar, pero sin aludir al principio de prohibición de exceso, SERRANO BUTRAGUEÑO, Ignacio, $L a$ transición del antiguo al nuevo Código Penal, La Ley, 1996-2, pp. 1466-1472, p. 1468. Por su parte, ante una situación de esta clase que se produjo en la sucesión habida entre el Código Penal español de 1973 y el de 1995 (concretamente, para el delito de impago de pensiones), la Fiscalía General del Estado, en su circular 2/1996, de 22 de mayo, señaló que "en la medida en que el legislador de 1995 por motivos que no es preciso ahora detallar ha querido que esos procesos no se inicien si no es con la anuencia del ofendido, a cuyo fin ha impuesto como requisito de procedibilidad la interposición de denuncia, se hace necesario subsanar el defecto sobrevenido. La subsanación se puede llevar a cabo llamando al perjudicado a tales
} 
consecuencia jurídico-penal se traduciría en una intervención penal que no respetaría la exigencia de necesidad de pena, atendidas las actuales valoraciones sociales, por lo que tal intervención devendría innecesaria y, por ende, estrictamente desproporcionada.

En síntesis, no es decisivo el carácter penal o procesal que tengan las disposiciones favorables por cuya retroactividad nos preguntamos, sino que lo es la vulneración o el respeto del principio de prohibición de exceso que su aplicación retroactiva comportaría.

\section{Solución del problema}

Como se ha señalado, antes del mes de mayo del año 2002 el giro fraudulento de cheque era un delito de acción penal pública. Su persecución se sometía a las disposiciones del juicio ordinario sobre crimen o simple delito del libro segundo del Código de Procedimiento Penal o a las del procedimiento ordinario del libro segundo del Código Procesal Penal, dependiendo de cuál fuera la región del país en la que el hecho tuviera lugar. A contar de la Ley $\mathrm{N}^{\circ} 19.806$, cuando la modalidad consiste en girar un cheque sin contar de antemano con fondos o créditos disponibles suficientes en cuenta corriente, o en retirar los fondos disponibles después de expedido el cheque, o en girarlo sobre cuenta corriente cerrada, el delito pasó a ser de acción privada, para cuya persecución se requiere, como es sabido, querella del ofendido.

De este modo, tuvo lugar una modificación favorable (la benignidad del cambio legal es evidente, ya que si para la persecución penal se exige querella de la víctima, se hace mucho más difícil la obtención de una condena que en los delitos de acción penal pública) en un ámbito de la legislación que se discute si pertenece al Derecho penal o al Derecho procesal penal. Pero, como lo he dicho más arriba, lo importante no es el carácter penal o procesal que tenga la mencionada modificación legal, sino si su inaplicación retroactiva o inmediata vulnera o no el principio de proporcionalidad en sentido amplio o de prohibición de exceso.

En mi opinión, en la sustanciación de todos los procedimientos penales por delitos de giro fraudulento de cheque la señalada modificación debería haber recibido aplicación inmediata. De lo contrario, se habría vulnerado la prohibición de exceso, la cual goza de consagración constitucional implícita. ${ }^{48}$ En efecto, si no se hubiera aplicado inmediatamente, se habría permitido que continuara funcionando el aparato de persecución penal sin que existiera necesidad de ello, de acuerdo con las valoraciones sociales actuales. Según éstas, es la propia víctima la que debe llevar el peso de la persecución penal, para lo cual se prevé un procedimiento especial -que en el antiguo sistema de enjuiciamiento criminal era el contemplado en el título II del libro III del

fines. Su oposición a que continúe el proceso se traducirá en la necesidad del sobreseimiento por ausencia de un requisito de procedibilidad. En otro caso éste deberá entenderse cumplido".

${ }^{48}$ Cfr. BASCUÑ ÁN RODRÍGUEZ, "Delitos contra intereses instrumentales”, cit. nota no 35, pp. 323 y s., quien sostiene que, lejos de resultar incompatible con dicho principio, el texto constitucional lo presupone en, al menos, dos de sus instituciones: el principio de subsidiariedad (artículo $1^{\circ}$, inciso tercero) y la garantía de intangibilidad del contenido esencial de los derechos fundamentales (artículo $19 \mathrm{~N}^{\circ} 26$ ).

En el caso de Argentina, la Corte Suprema de dicho país ha fundado el principio de proporcionalidad en el artículo 28 de su Constitución, cuyo tenor es el siguiente: "Los principios, garantías y derechos reconocidos en los anteriores artículos, no podrán ser alterados por las leyes que reglamenten su ejercicio". Ver CIANCIARDO, El principio de razonabilidad, cit. nota nº 35, pp. 38 y ss. 
OLIVER, Guillermo. "Modificaciones en la regulación del delito de giro fraudulento de cheque: análisis desde la teoría de la sucesión de leyes".

Código de Procedimiento Penal y en el actual, el previsto en el título II del libro IV del Código Procesal Penal-. Según estas mismas valoraciones, la intervención penal sólo resultaría satisfactoria si la víctima del delito -el beneficiario del cheque- estuviera de acuerdo con que ésta se lleve adelante y exteriorizara su conformidad por medio de una querella, manifestando dicha voluntad a lo largo de todo el procedimiento especial señalado. Cualesquiera fueran las razones por las que la víctima pudiera no estar de acuerdo en el inicio de un proceso o por las que se pudiera desistir de la querella o abandonar la acción, esas razones se estiman valiosas, por lo que llevar adelante la intervención penal e imponer una pena siguiendo con la tramitación ordinaria, como si se tratara de un delito de acción penal pública, implicaría no respetar la exigencia de necesidad de pena, y se llegaría así a la imposición de una sanción innecesaria y, por ende, desproporcionada.

En todo caso, si se quisiera insistir en que la solución del problema planteado pasa por determinar previamente la naturaleza sustantiva o adjetiva de la comentada modificación legal, la conclusión no cambiaría, porque la asignación de uno u otro carácter conduce al mismo resultado. Por un lado, hay quienes, a partir de las razones político criminales que inspiraron dicha reforma, han sostenido que ésta constituyó una verdadera decisión sustantiva, al cambiar la naturaleza jurídica de la figura del giro fraudulento de cheque. ${ }^{49}$ Pues bien, si se trata de una modificación penal de orden sustantivo, prácticamente la unanimidad de la doctrina nacional plantea que debe darse aplicación retroactiva a esta clase de leyes cuando son más favorables, a partir de lo dispuesto en el artículo $19 \mathrm{~N}^{\mathrm{o}} 3$, inciso séptimo, de la Constitución y en el artículo 18, incisos segundo, tercero y cuarto del Código Penal. ${ }^{50}$

La otra posibilidad, que también ha sido planteada, es asignar a la señalada modificación legal naturaleza puramente procesal, caso en el cual entraría a jugar el artículo transitorio de la citada Ley $\mathrm{N}^{\circ} 19.806$, que se ha transcrito más arriba, el cual estableció una alteración de la regla sobre aplicación inmediata o in actum de las modificaciones legales de orden procesal prevista en el artículo 24 de la aún vigente Ley sobre efecto retroactivo de las leyes. Esta última disposición reza así:

"Las leyes concernientes a la substanciación y ritualidad de los juicios prevalecen sobre las anteriores desde el momento en que deben empezar a regir. Pero los términos que hubiesen empezado a correr y las actuaciones y diligencias que ya estuvieren iniciadas se regirán por la ley vigente al tiempo de su iniciación”.

Conforme a este precepto, si la modificación fuera procesal, debería haberse aplicado desde el momento de su publicación en el Diario Oficial. Pero como el artículo

\footnotetext{
49 Así, entre otros, OSSANDÓN WIDOW, María Magdalena, "El giro doloso de cheques como delito de acción privada", La Semana Jurídica, año 3, No 137, semana del 23 al 29 de junio de 2003, p. 5; KÜNSEMÜLLER LOEBENFELDER, Carlos, "Un tema clásico: giro fraudulento de cheque", Revista del Abogado. Publicación del Colegio de Abogados de Chile, $N^{\circ} 28$, julio 2003, pp. 10-12, p. 10.

${ }^{50}$ Entre otros, véanse CURY URZÚA, Enrique, Derecho Penal. Parte General, $7^{\mathrm{a}}$ edición, Santiago: Ed. Universidad Católica de Chile, 2005, p. 228; POLITOFF LIFSCHITZ, Sergio; MATUS ACUÑA, Jean Pierre; RAMÍREZ GUZMÁN, María Cecilia, Lecciones de Derecho penal chileno. Parte general, Santiago: Editorial Jurídica de Chile, 2004, p. 131; ETCHEBERRY, Alfredo, Derecho Penal. Parte General, t. I, $3^{\text {a }}$ edición, Santiago: Editorial Jurídica de Chile, 1998, p. 143. Excepcionalmente y contra la doctrina dominante, BASCUÑÁN RODRÍGUEZ, "La ley penal", cit. nota no 33, p. 210, afirma que el texto constitucional -el artículo $19 \mathrm{~N}^{\circ} 3$, inciso séptimo- permite la retroactividad de la ley penal más favorable, pero no la impone.
} 
transitorio de la Ley $\mathrm{N}^{\circ} 19.806$ estableció que aquellas de sus normas "relativas al ejercicio de la acción penal pública, la dirección de la investigación y la protección de las víctimas y testigos, a la competencia en materia penal y a la ley procesal penal aplicable" entrarían en vigencia gradualmente en las distintas regiones del país, conforme al calendario previsto en el artículo $4^{\circ}$ transitorio de la Ley $\mathrm{N}^{\circ} 19.640$, Orgánica Constitucional del Ministerio Público, su entrada en vigor se pospuso. Pues bien, como los plazos que en dicho calendario se mencionan para las diversas regiones del país ya se encuentran vencidos con creces, no hay razón alguna para negar aplicación a la modificación hecha por la Ley $\mathrm{N}^{\circ} 19.806$ en los procedimientos que aún puedan estar tramitándose por delitos de giro fraudulento de cheque cometidos con anterioridad a su entrada en vigor.

\section{Conclusiones}

Para finalizar este trabajo he decidido dejar establecidas, a modo de conclusiones, las principales afirmaciones hechas a lo largo del mismo:

1. Es el principio de proporcionalidad en sentido amplio o prohibición de exceso, con sus exigencias de idoneidad, necesidad y proporcionalidad en sentido estricto, el verdadero fundamento de la retroactividad in bonam partem.

2. El principio de prohibición de exceso obliga a la aplicación inmediata o retroactiva de los cambios favorables en la legislación procesal penal.

3. La prohibición de exceso, que goza de consagración constitucional implícita, hizo obligatorio que en la sustanciación de todos los procedimientos penales por delitos de giro fraudulento de cheque se diera aplicación inmediata a la modificación hecha por la Ley $\mathrm{N}^{\mathrm{o}}$ 19.806. De lo contrario, de llevarse adelante la intervención penal continuando con la tramitación ordinaria, como si de delitos de acción pública se tratara, las eventuales sanciones que se hubieren impuesto no habrían respetado la exigencia de necesidad de pena, siendo sanciones innecesarias y, por ende, desproporcionadas.

4. Ninguna importancia tiene en la solución a que se ha arribado el hecho de que a la comentada modificación legal se le asigne una naturaleza penal sustantiva o adjetiva. Se siga uno u otro camino, el resultado es el mismo y la prohibición de exceso lo torna obligatorio.

\section{BIBLIOGRAFÍA}

AGUADO CORREA, Teresa, El principio de proporcionalidad en derecho penal, Madrid: Edersa, 1999, pp. 149 y ss.

ALBÁN GÓMEZ, Ernesto, Manual de Derecho Penal Ecuatoriano, Quito: Ediciones Legales, 1995, pp. 59 y ss.

ANTÓN ONECA, José, Derecho Penal, $2^{\text {a }}$ edición anotada y puesta al día, Madrid: Akal, 1986, pp. 126 y ss.

ARANGIO RUIZ, Gaetano, "Intorno all'efficacia delle leggi penali temporanee", Rivista Penale, No 44, (1896), pp. 5-22.

ARMENTA DEU, Teresa, Lecciones de Derecho Procesal Penal, $2^{\mathrm{a}}$ edición, Madrid: Marcial Pons, 2004, pp. 70 y ss.

ARROYO ZAPATERO, Luis, "Principio de legalidad y reserva de ley en materia penal", Revista Española de Derecho Constitucional, № 8, Madrid, mayo - agosto (1983), pp. 9-46. 
OLIVER, Guillermo. "Modificaciones en la regulación del delito de giro fraudulento de cheque: análisis desde la teoría de la sucesión de leyes".

ASENCIO MELLADO, José María, Derecho Procesal Penal, $3^{\text {a }}$ edición, Valencia: Tirant lo Blanch, 2004, pp. 139 y ss.

BACIGAlUPO, Enrique, Principios de Derecho Penal. Parte general, $5^{\text {a }}$ edición, Madrid: Akal, 1998, pp. 55 y ss.

BASCUÑÁN RODRÍGUEZ, Antonio, "La ley penal”, Comentario de la jurisprudencia del año 2003 de la Corte Suprema y del Tribunal Constitucional. Revista de Derecho de la Universidad Adolfo Ibáñez, No 1, (2004), pp. 209-227.

"Delitos contra intereses instrumentales", Comentario de la jurisprudencia del año 2003 de la Corte Suprema y del Tribunal Constitucional. Revista de Derecho de la Universidad Adolfo Ibáñez, n 1, (2004), pp. 291-345.

, "La aplicación de la ley penal más favorable",

Revista Jurídica de la Universidad de Puerto Rico, volumen 69, N 1, (2000), pp. 29-133,

"La aplicación de la ley penal derogada", Revista del Abogado. Publicación del Colegio de Abogados de Chile, $\mathrm{N}^{\mathrm{o}}$ 17, noviembre (1999), pp. 10-13

BÉRAUD, R., "La non-rétroactivité des lois nouvelles plus douces?", Revue de Science Criminelle et de Droit Pénal Comparé, enero - marzo (1949), $\mathrm{n}^{\circ}$ 1, pp. 7-20.

BIDART CAMPOS, Germán J., "La irretroactividad de la ley penal y el principio de la ley más benigna", Revista de Derecho penal y Criminología, Buenos Aires: (1970), pp. 333-345.

BORDALÍ SALAMANCA, Andrés, "Temas de derecho procesal constitucional”, Fallos del mes, Valdivia, (2003), pp. 68 y ss.

BUSTOS RAMÍREZ, Juan; HORMAZÁBAL MALARÉE, Hernán, Lecciones de derecho penal, vol. I, Madrid: Trotta, 1997, p. 107.

BUSTOS RAMÍREZ, Juan, Manual de Derecho Penal. Parte General, $4^{\mathrm{a}}$ edición aumentada, corregida y puesta al día por Hernán Hormazábal Malarée, Barcelona: PPU 1994, pp. 107 y ss.

CADOPPI, Alberto, "Il principio di irretroattività" en: INSOLERA, G.; MAZZACUVA, N.; PAVARINI, M.; ZANOTTI, M. (a cura di), Introduzione al sistema penale, vol. I,Turín: Giappichelli, 1997, pp. 154-189.

CARACCIOLI, Ivo, Manuale di Diritto Penale. Parte generale, Padova: Cedam, 1998, p. 90.

CARBONELL MATEU, Juan Carlo, Derecho penal: concepto y principios constitucionales, $3^{\text {a }}$ edición, Valencia: Tirant lo Blanch, 1999, pp. 140 y ss.

CARNELUTTI, Francesco, "Riflessioni sulla successione di leggi penali processuali" en CARNELUTTI, Francesco, Questioni sul processo penale, Bolonia: Cesare Zuffi, 1950, pp. 187-200.

CEREZO MIR, Curso de Derecho penal español. Parte general, t. I, $6^{\text {a }}$ edición, Madrid: Tecnos, 2004, p. 227.

CIANCIARDO, Juan, El principio de razonabilidad. Del debido proceso sustantivo al moderno juicio de proporcionalidad, Buenos Aires: Editorial Ábaco de Rodolfo Depalma, 2004, pp. 61 y ss.

COBO DEL ROSAL, Manuel; VIVES ANTÓN, Tomás Salvador, Derecho Penal. Parte General, $5^{\text {a }}$ edición, Valencia: Tirant lo Blanch, 1999, pp. 99 y ss. ,"Comentario al art. 2 del Código Penal” en: COBO DEL ROSAL (dir.), Comentarios al Código Penal, t. I, Madrid: Edersa, 1999, pp. 69-86. 
, "Retroactividad de

las disposiciones favorables en materia de contrabando" en: COBO DEL ROSAL, Manuel (dir.); BAJO FERNÁNDEZ, Miguel (coord.), Comentarios a la Legislación Penal, t. III, Madrid: Edersa, 1984, Delitos e infracciones de contrabando, pp. 583-585.

CUELLO CALÓN, Eugenio, Adiciones a la $4^{a}$ edición de la traducción de Elementos de derecho penal de Enrique Pessina, Madrid: Reus, 1936, pp. 220 y ss.

CUEllo CONTRERAS, Joaquín, El Derecho Penal español. Parte general, $3^{\mathrm{a}}$ edición, Madrid: Dykinson, 2002, pp. 246 y ss.

CUERDA ARNAU, María Luisa, "Aproximación al principio de proporcionalidad en derecho penal" en: GONZÁLEZ CUSSAC, José Luis et al, Estudios jurídicos en memoria del profesor Dr. D. José Ramón Casabó Ruiz, vol. I, Valencia: Universidad de Valencia. Instituto de Criminología, 1997, pp. 447-491.

CUERDA RIEZU, Antonio, "La aplicación retroactiva de las leyes favorables y el principio de legalidad penal en clave constitucional" en: BALADO, M.; GARCÍA REGUEIRO, J. A.; (dirs.), La Declaración Universal de los Derechos Humanos en su 50 aniversario, Barcelona: Bosch, 1998, pp. 275-290. "Irretroactividad y retroactividad de la ley penal", en: Enciclopedia Jurídica Básica, vol. III, Madrid: Civitas, 1995, pp. 3769-3771.

CURY URZÚA, Enrique, Derecho Penal. Parte General, $7^{\mathrm{a}}$ edición, Santiago: Ed. Universidad Católica de Chile, 2005, p. 228.

DE LA OLIVA SANTOS, Andrés; ARAGONESES MARTÍNEZ, Sara; HINOJOSA SEGOVIA, Rafael; MUERZA de CASABÓ RUIZ, José Ramón, "Comentario al art. 24" en: CÓRDOBA RODA, Juan; RODRÍGUEZ MOURULLO, Gonzalo; DEL TORO MARZAL, Alejandro; CASABÓ RUIZ, José Ramón, Comentarios al Código Penal, t. II, Barcelona: Ariel, 1972, pp. 44-5.8

DE LUCA, La garantía constitucional de retroactividad de ley penal más benigna y su violación en las leyes penales económicas en blanco con el pretexto de subsistencia de la lesión al bien jurídico protegido, ponencia presentada en la Comisión V del Congreso Internacional de Derecho Penal " $75^{\circ}$ Aniversario del Código Penal", organizado por la Facultad de Derecho y Ciencias Sociales de la Universidad de Buenos Aires, Argentina, entre el 11 y el 14 de agosto de 1997, p. 4.

DE VICENTE MARTÍNEZ, Rosario, El principio de legalidad penal, Valencia: Tirant lo Blanch, 2004, p. 65.

DEL ROSAL, Juan, "Consumación y aplicación de ley penal en el delito continuado", Anuario de Derecho Penal y Ciencias Penales, (1948), pp. 277-291.

DRAGONETTI, Mario, “¿Irretroactividad de la ley penal más benigna en materia de infracciones a la ley 12.830 ? El código penal como derecho represivo común en situaciones anteriores a la ley 13.492", Revista Jurídica Argentina La Ley, $\mathrm{n}^{\circ}$ 52, Buenos Aires, octubre - diciembre (1948), pp. 433-439.

DUARTE, José, "A lei penal no tempo. Comentários ao art. $2^{\circ}$ do Código Penal", Revista Forense, volumen XC, Sao Paulo, (1942), pp. 622-631.

ESPARZA, Julio; TOMÉ GARCÍA, José Antonio, Derecho Procesal Penal, $7^{\text {a }}$ edición, Madrid: Editorial Universitaria Ramón Areces, 2004, pp. 402 y ss.

ETCHEBERRY, Alfredo, Derecho Penal. Parte General, t. I, $3^{\text {a }}$ edición, Santiago: Editorial Jurídica de Chile, 1998, p. 143.

FIANDACA, Giovanni; MUSCO, Enzo, Diritto Penale. Parte Generale, $3^{\text {a }}$ edición, Bolonia: Zanichelli, 1995, reimpresión, 1999, p. 79. 
OLIVER, Guillermo. "Modificaciones en la regulación del delito de giro fraudulento de cheque: análisis desde la teoría de la sucesión de leyes".

FIERRO, Guillermo, Legalidad y retroactividad de las normas penales. Fuentes del derecho. Legalidad en el derecho tributario, procesal penal y aduanero, Buenos Aires: Hammurabi, 2003, pp. 312 y ss. "Los delitos permanentes y la ley más benigna", Jurisprudencia Argentina, Buenos Aires, 2000, tomo IV, p. 575.

La ley penal y el derecho transitorio. Retroactividad $e$ irretroactividad, Buenos Aires: Depalma, 1978, pp. 281 y ss.

FIORE, Carlo, Diritto Penale. Parte Generale, t. I, Turín: UTET, 1993, p. 89.

FIORE, Pascuale, De la irretroactividad e interpretación de las leyes. Estudio crítico y de legislación comparada, $3^{\text {a }}$ edición, Trad. AGUILERA DE PAZ, Madrid: Reus, 1927, pp. 441 y ss.

FRÍGOLS I BRINES, Eliseu, Fundamentos de la sucesión de leyes en el derecho penal español. Existencia y aplicabilidad temporal de las normas penales, Barcelona: Bosch, 2004, p. 407.

El principio de irretroactividad y la sucesión de leyes penales. Una perspectiva desde el derecho comparado, San José de Costa Rica: Editorial Jurídica Continental, 2002, p. 201.

GALLEGO DÍAZ, Manuel, "Prescripción penal y prohibición de retroactividad", Revista General de Legislación y Jurisprudencia, enero (1986), pp. 27-48.

GALLO, Marcello, "Interpretazione della Corte costituzionale e interpretazione giudiziaria (a proposito delle garanzie della difesa nell'istruzione sommaria)", Rivista Italiana di Diritto e Procedura Penale, (1965), pp. 200-216.

GÓMEZ LÓPEZ, Jesús Orlando, Tratado de derecho penal. Parte general, t. I, Bogotá: Doctrina y ley, 2001, p. 844.

GONZÁLEZ-CUÉLLAR SERRANO, Nicolás, Proporcionalidad y derechos fundamentales en el proceso penal, Madrid: Colex, 1990, p. 17.

GONZÁlEZ TAPIA, María Isabel, Determinación del tiempo de comisión del delito, Granada: Comares, 2002, pp. 223 y ss.

GÓRRIZ ROYO, Elena, "La problemática de las remisiones normativas y de la retroactividad de las leyes penales favorables en relación a los delitos sobre la ordenación del territorio", Revista de Ciencias Penales, volumen 1, n 1, (1998), pp. 73-99.

GROUBER, Alexandre, Du conflit des lois d'incrimination et de pénalité dans le temps, París: Rousseau et Cie., 1915, pp. 114 y ss.

HENNAU, Christiane; VERHAEGEN, Jacques, Droit Pénal General, $2^{\mathrm{a}}$ edición, Bruselas: Bruylant, 1995, p. 87.

HUERTA TOCILDO, Susana, "Principio de legalidad y normas sancionadoras" en: $E l$ principio de legalidad. Actas de las V Jornadas de la Asociación de Letrados del Tribunal Constitucional. Cuadernos y Debates, N 103, Madrid, 2000, pp. 11-76,

, "El derecho fundamental a la legalidad penal", Revista Española de Derecho Constitucional, No 39, Madrid, (1993), pp. 81-113.

HURTADO POZO, José, Manual de Derecho Penal. Parte general, $2^{\mathrm{a}}$ edición, Lima: Eddili, 1987, p. 300.

JAKOBS, Gunther, Derecho Penal. Parte General. Fundamentos y teoría de la imputación, traducción de la $2^{\mathrm{a}}$ edición alemana de Joaquín Cuello Contreras y José Luis Serrano González de Murillo, Madrid: Marcial Pons, 1997.

JESCHECK, Hans-Heinrich, Tratado de derecho penal. Parte general, Trad. MANZANARES SAMANIEGO, José Luis, de la $4^{\text {a }}$ edición alemana, Granada: Comares, 1993, p. 23. 
JIMÉNEZ DE ASÚA, Luis, Tratado de derecho penal, t. II, $5^{\text {a }}$ edición, Buenos Aires: Losada, 1950, p. 628.

JIMÉNEZ RODRÍGUEZ, J. Héctor, "Límites temporales de la ley penal: aspectos sustanciales y procesales", Temas de Derecho Penal Colombiano, $\mathrm{n}^{\circ} 14$, Medellín, (1981), pp. 33-45.

KILIBARDA, Danilo, "La ley penal más benigna y el delito de lesiones leves", Revista Jurídica Argentina La Ley, $\mathrm{n}^{\circ}$ 135, Buenos Aires, julio - septiembre (1969), pp. 145-149.

KÜNSEMÜLLER LOEBENFELDER, Carlos, "Un tema clásico: giro fraudulento de cheque", Revista del Abogado. Publicación del Colegio de Abogados de Chile, $\mathrm{N}^{\circ}$ 28, julio 2003, pp. 10-12.

LABATUT GLENA, Gustavo, Derecho Penal, t. I, 9a edición actualizada por el profesor Julio Zenteno Vargas, Santiago: Editorial Jurídica de Chile, 2000, p. 51.

LANDECHO VELASCO, Carlos María; MOLINA BLÁZQUEZ, Concepción, Derecho Penal Español. Parte general, $7^{\mathrm{a}}$ edición, Madrid: Tecnos, 2004, p. 153.

LANDROVE DÍAZ, Gerardo, Introducción al Derecho Penal español, $5^{\mathrm{a}}$ edición revisada y puesta al día en colaboración con María Dolores Fernández Rodríguez, Madrid: Tecnos, 2000, pp. 119 y ss.

LASCURAIIN SÁNCHEZ, "Delito fiscal y retroactividad" en: MIR PUIG, Santiago et al, Estudios de Derecho Penal Económico, Caracas: Livtosca, 2002, pp. 433-469

LASCURAÍN SÁNCHEZ, Juan Antonio, Sobre la retroactividad penal favorable, Madrid: Civitas, 2000, pp. 25 y 28.

LEIRIA, Antònio José Fabricio, Teoria e aplicação da lei penal, Sao Paulo: Saraiva, 1981, p. 79.

LUZÓN PEÑA, Diego-Manuel, Curso de Derecho penal. Parte general, t. I, Madrid: Universitas, 1996, p. 183.

MANTOVANI, Fernando, Diritto Penale. Parte Generale, $3^{a}$ edición, Padova: Cedam, 1992, pp. 118 y ss.

MARTÍNEZ-BUJÁN PÉREZ, Carlos, Derecho Penal Económico. Parte General, Valencia: Tirant lo Blanch, 1998, pp. 127 y ss.

, Los delitos contra la hacienda pública y la seguridad social, Madrid: Tecnos, 1995, pp. 121 y ss.

MATHIEU, Gilles, "L'application de la loi pénale dans le temps (dans la perspective du nouveau Code Pénal)", Revue de Science Criminelle et de Droit Pénal Comparé, (1995), pp. 257-270.

MAURACH, Reinhart, Tratado de Derecho Penal, Trad. CÓRDOBA RODA, Juan, Barcelona: Ariel, 1962, pp. 142 y ss.

MEJÍA ESCOBAR, Carlos, “Apunte sobre la favorabilidad”, Temas de Derecho Penal Colombiano, $\mathrm{n}^{\circ}$ 14, (1981), pp. 47-57.

MEZGER, Edmund, Tratado de derecho penal, t. I, trad. de la $2^{\mathrm{a}}$ edición alemana de RODRÍGUEZ MUÑOZ, José Arturo, con notas, Madrid, 1946, p. 130.

MIR PUIG, Santiago, Derecho Penal. Parte General, $7^{\mathrm{a}}$ edición, Barcelona: Reppertor, 2004, pp. 131 y ss.

MORILlAS CUEVA, Lorenzo, Derecho Penal. Parte General. Fundamentos conceptuales y metodológicos del Derecho penal. Ley penal, Madrid: Dykinson, 2004, p. 219.

MORILLAS CUEVA, Lorenzo; RUIZ ANTÓN, Luis Felipe, Manual de Derecho Penal (parte general), Madrid: Editoriales de Derecho Reunidas, 1992, p. 85.

MUSCO, Mauricio, La riformulazione dei reati. Profili di diritto intertemporale, Milán:Giuffrè, 2000, pp. 20 y ss. 
OLIVER, Guillermo. "Modificaciones en la regulación del delito de giro fraudulento de cheque: análisis desde la teoría de la sucesión de leyes".

NOVOA MONREAL, Eduardo, Curso de Derecho Penal Chileno, t. I, $2^{\text {a }}$ edición, Santiago: Editorial Jurídica Ediar-Conosur, 1985, pp. 199 y ss.

OCTAVIO DE TOLEDO Y UBIETO, Emilio, Sobre el concepto del Derecho penal, Madrid: Facultad de Derecho de la Universidad de Madrid, 1981, p. 325.

OLIVER CALDERÓN, Guillermo, Retroactividad e irretroactividad de las leyes penales, Santiago: Editorial Jurídica de Chile, 2007, pp. 262 y ss.

OSSANDÓN WIDOW, María Magdalena, "El giro doloso de cheques como delito de acción privada", La Semana Jurídica, año 3, No 137, semana del 23 al 29 de junio de 2003 , p. 5.

PACHECO, Joaquín Francisco, El Código Penal concordado y comentado, reimpresión de la $3^{\text {a }}$ edición de 1867, Madrid: Edisofer, 2000, p. 303.

PADOVANI, Tullio, "Decreto-legge non convertito e norme penali di favore, in bilico tra opposte esigenze costituzionali", Rivista Italiana di Diritto e Procedura Penale, 1985, pp. 819-835, pp. 826 y ss.

, "Tipicità e successione di leggi penali. La modificazione legislativa degli elementi della fattispecie incriminatrice o della sua sfera di applicazione, nell'ambito dell'art. 2,2 e $3^{\circ}$ comma, C.P.", Rivista Italiana di Diritto e Procedura Penale, (1982), pp.1354-1389.

PALAZZO, Francesco, Introduzione ai principi del Diritto penale, Turín: Giappichelli, 1999, p. 296.

PATALANO, Vicenzo, "Reato permanente e successione di leggi penali nel tempo", Giurisprudenza di Merito, Parte Segunda, (1975), pp. 54-60.

PEÑA CABRERA, Raúl, Tratado de Derecho Penal. Estudio programático de la parte general, $3^{\text {a }}$ edición corregida y aumentada con la colaboración de Carlos Atocsa García, José A. Caro John, Reiner Chocano Rodríguez y Sofía Laqui Pizarro, Lima: Grijley, 1997, reimpresión de 1999, p. 236.

PÉREZ ROYO, Fernando, "La aplicación retroactiva de la ley penal más favorable en los casos de modificaciones en la normativa tributaria", Revista Técnica Tributaria $\mathrm{n}^{\circ}$ 43, octubre - diciembre (1998), pp. 75-88.

PESSINA, Enrique, Elementos de Derecho Penal, $4^{\mathrm{a}}$ edición, Trad. GONZÁLEZ DEL CASTILLO, Hilarión, prologado y adicionado con arreglo al derecho español por Félix de Aramburu y Zuloaga, anotada conforme a la legislación vigente y adicionada con las doctrinas científicas modernas por Eugenio Cuello Calón, Madrid: Reus, 1936, p. 214.

PISAPIA, G. Domenico, "Impugnabilità del mandato di cattura e successione di leggi processuali”, Rivista Italiana di Diritto Penale, (1957), pp. 50-59.

POLITOFF LIFSCHITZ, Sergio; MATUS ACUÑA, Jean Pierre; RAMÍREZ GUZMÁN, María Cecilia, Lecciones de Derecho penal chileno. Parte general, Santiago: Editorial Jurídica de Chile, 2004, p. 131.

PUENTE SEGURA, Leopoldo, "Delitos contra la salud pública. Posibilidad de revisión de sentencias al amparo del nuevo artículo 376 del Código Penal", La Ley 20045,pp. 1298-1303.

PULITANÒ, Domenico, "Commentario al articolo 2" en: CRESPI, Alberto; STELLA, Federico; TAIPA DE CARVALHO, Americo, Sucessão de leis penais, Coimbra: Coimbra Editora, 1990, p. 195.

QUINTERO OLIVARES, Gonzalo; MORALES PRATS, Fermín; PRATS CANUT, Josep, Manual de Derecho Penal. Parte General, $3^{\text {a }}$ edición, Navarra: Aranzandi, 2002, p. 174. 
RAGUÉS I VALLÈS, Ramón, La prescripción penal. Fundamento y aplicación. Texto adaptado a la LO 15/2003 de reforma del Código penal, Barcelona: Atelier, 2004, pp. 40 y ss.

RASSAT, Michèle-Laure, Droit pénal, París: Presses Universitaires de France, 1987, pp. 206 y ss.

RIVAS GODIO, Luis Enrique, "La iniciativa privada en las lesiones leves y el procedimiento penal intertemporal: ámbito de validez temporal de la nueva ley penal", Revista Jurídica Argentina La Ley, $\mathrm{n}^{\mathrm{o}}$ 130, Buenos Aires, abril - junio (1968), pp. 1147-1153.

ROBERT, Jacques-Henri, Droit pénal general, $3^{\mathrm{a}}$ edición, París: Presses Universitaires de France, 1998, p. 144

RODRÍGUEZ MOURULLO, Gonzalo, Delito y pena en la jurisprudencia constitucional, Madrid: Civitas, 2002, p. 47.

, "Comentario al art. 2", RODRÍGUEZ

MOURULLO (dir.); JORGE BARREIRO (coord.), Comentarios al Código Penal, Madrid: Civitas, 1997, p. 31

Civitas, 1978, pp. 132 y ss.

, Derecho Penal. Parte General, Madrid:

ROMANO, Mario, Commentario sistemático del Codice Penale, vol. I, $2^{\text {a }}$ edición, Milán: Giuffrè, 1995, p. 59.

ROUBIER, Paul, Le Droit Transitoire (conflits des lois dans le temps), $2^{\mathrm{a}}$ edición, París: Dalloz et Sirey, 1960, p. 453.

ROXIN, Claus, Derecho Penal. Parte General, t. I, Trad. de la $2^{\mathrm{a}}$ edición alemana y notas, LUZÓN PEÑA, Diego Manuel et. al., Madrid: Civitas, 1997, pp. 144 y ss.

RUBBRECHT, J.; DECLERCQ, R., "La non-rétroactivité des lois pénales en Droit Belge", Revue de Droit International et de Droit Comparé, Bruselas: (1950), XXVII, número especial, pp. 214-221.

RUIZ DE ERENCHUM ARTECHE, Eduardo, “El 'sistema de sucesión de leyes' y la problemática de la redención de penas por el trabajo. Valoración de las aportaciones del Tribunal Supremo", Revista del Poder Judicial, No 48, (1997), pp. 323-386.

RUIZ ROBLEDO, Agustín, El derecho fundamental a la legalidad punitiva, Valencia: Tirant lo Blanch, 2003, p. 198.

SÁINZ CANTERO, José, Lecciones de Derecho Penal. Parte general, $3^{\mathrm{a}}$ edición, Barcelona: Bosch, 1990, pp. 398 y ss.

SANGUINÉ, Odone, Prisión provisional y derechos fundamentales, Valencia: Tirant lo Blanch, 2003, pp. 638 y ss.

SERRANO ALBERCA, José Manuel, "Comentario al art. 25 de la Constitución” en: GARRIDO FALLA, Fernando et al, Comentarios a la Constitución, $3^{\text {a }}$ edición, Madrid: Civitas, 2001, pp. 577-612.

SERRANO BUTRAGUEÑO, Ignacio, "Retroactividad, ultra-actividad y extractividad de las normas penales", La Ley, No 4530, 29 de abril de 1998, pp.1-6

Ignacio, La transición del antiguo al nuevo Código Penal, La Ley, 1996-2, pp. 1466-1472

SILVA SÁNCHEZ, Jesús María, "Legislación penal socio-económica y retroactividad de disposiciones favorables: el caso de las 'leyes en blanco", en: ARROYO ZAPATERO, Luis et al, Hacia un derecho penal económico europeo, Madrid: BOE, 1995, pp. 697-722.

Barcelona: Bosch, 1992, p. 261.

Aproximación al derecho penal contemporáneo, 
OLIVER, Guillermo. "Modificaciones en la regulación del delito de giro fraudulento de cheque: análisis desde la teoría de la sucesión de leyes".

SINISCALCO, Marco, Irretroattività delle leggi in materia penale. Disposizioni sostanziali e disposizioni processuali nella disciplina della successione di leggi, Milán: Giuffrè, 1969, reimpresión 1987, p. 149.

SPASARI, Mario, Diritto Penale e Costituzione, Milán: Giuffrè, 1966, p. 42.

THÉODOSIADÉS, Miltiade, Essai sur la non-rétroactivité des lois, París: Abel Pilon, 1866, p. 199.

VASSALLI, Giuliano, “Abolitio criminis e principii costituzionali”, Rivista Italiana di Diritto e Procedura Penale, (1983), pp. 377-414.

VELÁSQUEZ VELÁSQUEZ, Fernando, "El principio de prohibición de exceso en el Código penal colombiano" en: DE FIGUEIREDO DIAS, Jorge; SERRANO GÓMEZ, Alfonso; POLITOFF LIFSCHITZ, Sergio; ZAFFARONI, Eugenio Raúl (dirs.); GUZMÁN DÁLBORA, José Luis, El penalista liberal. Controversias nacionales e internacionales en derecho penal, procesal penal y criminología. Homenaje a Manuel de Rivacoba y Rivacoba, Buenos Aires: Hammurabi, 2004, pp. 363-391.

Bogotá: Temis, 1997, p. 145

, Derecho Penal. Parte General, $3^{\text {a }}$ edición,

YMAZ VIDELA, Martín Rafael, "La sucesión de leyes penales: el artículo 24 de la ley 24.769 y la derogación de la ley 23.771", El Derecho, No 176, Buenos Aires, (1998), pp. 1003-1010.

ZAFFARONI, Eugenio Raúl; ALAGIA, Alejandro; SLOKAR, Alejandro, Derecho Penal. Parte General, 2a edición, Buenos Aires: Ediar, 2003, p. 121.

ZUCCALÀ, Giuseppe, Comentario breve al Codice Penale, Padova: Cedam, 2003, pp. $17-28$. 